DEMOGRAPHIC RESEARCH

VOLUME 32, ARTICLE 16, PAGES 487-532

PUBLISHED 18 FEBRUARY 2015

http://www.demographic-research.org/Volumes/Vol32/16/

DOI: 10.4054/DemRes.2015.32.16

Research Article

Urban fertility responses to local government programs: Evidence from the 1923 - 1932 U.S.

\title{
Jonathan Fox
}

Mikko Myrskylä

(C) 2015 Jonathan Fox \& Mikko Myrskylä.

This open-access work is published under the terms of the Creative Commons

Attribution NonCommercial License 2.0 Germany, which permits use, reproduction \& distribution in any medium for non-commercial purposes, provided the original author(s) and source are given credit.

See http://creativecommons.org/licenses/by-nc/2.0/de/ 


\section{Table of Contents}

$1 \quad$ Introduction 488

$1.1 \quad$ Historical U.S. fertility declines and a 1920s acceleration 489

1.2 A 1920s fertility story 491

$2 \quad$ Public programs and changes in fertility 494

$2.1 \quad$ Conservation of child life 494

2.2 Charity for children and mothers \& outdoor care of poor 496

$3 \quad$ Measuring local fertility $\quad 497$

$4 \quad$ U.S. municipal fertility, $1920-1932$

5 Data 500

$6 \quad$ Model and estimation $\quad 503$

7 Conclusion $\quad 512$

8 Acknowledgements 513

$\begin{array}{ll}\text { References } & 514\end{array}$

Appendices $\quad 519$

A Alternative measures of municipal fertility rates $\quad 519$

B Additional sensitivity analyses $\quad 522$

B.1 Including city-specific trends 522

B.2 Including state-specific trends 523

B.3 Distributed lags 523

B.4 Arellano-Bond Dynamic Panel Model 524

C Data appendix 530 


\title{
Urban fertility responses to local government programs: Evidence from the 1923 - 1932 U.S.
}

\author{
Jonathan Fox ${ }^{1}$ \\ Mikko Myrskylä ${ }^{2}$
}

\begin{abstract}
BACKGROUND

During the 1920s and early 1930s, U.S. fertility declined overall but with large regional variations. Changes in foreign born populations explain only part of this. Differences in public health and poverty relief programs may further help explain these declines because of their potential impact on fertility determinants, in particular on breastfeeding and child mortality.
\end{abstract}

\section{OBJECTIVE}

We investigate whether public health investments in child health (conservation of child life programs) and poverty relief (outdoor care of poor or charity for children and mothers) affected fertility for U.S. cities over 100,000 persons between 1923 and 1932.

\section{METHODS}

We analyze data covering 64 cities between 1923-1932 that include birth information from the U.S. Birth, Stillbirth and Infant Mortality Statistics volumes and city financial information from the Financial Statistics of Cities volumes. Time and city fixed-effects models are used to identify the impact of public investments on fertility.

\section{RESULTS}

Fixed effects estimates indicating the conservation of child life programs explain about $10 \%$ of the fertility change between 1923 and 1932. Outdoor care of poor did not seem to be related to fertility. Investments in charity for children and mothers were associated with fertility increases, possibly because poorer areas experienced relative increases in both higher fertility and charitable spending.

\section{CONCLUSIONS}

Public spending on child health was strongly related to decreasing fertility in the U.S. during the 1920s, possibly because of increased breastfeeding and decreased child

\footnotetext{
${ }^{1}$ Freie Universität Berlin, Germany. E-Mail: jfox @ zedat.fu-berlin.de.

${ }^{2}$ London School of Economics and Political Science, London, UK. Max Planck Institute for Demographic Research, Rostock, Germany. University of Helsinki, Helsinki, Finland.
} 
mortality. This leads to a better understanding of the 1920s fertility decline and highlights how public policy may affect fertility.

\section{Introduction}

During the 1920s and early 1930s, before the enactment of the New Deal, fertility in large American urban areas trended downward, with the Total Fertility Rate (TFR) dipping below modern day replacement levels (about 2.3) likely for the first time. ${ }^{3}$ While fertility across large urban areas declined on average, cities varied in their fertility trajectories. There is no consensus as to what caused this variation, but in this paper we present empirical evidence showing that at least part of the variation in fertility outcomes across the large U.S. municipalities during the 1920s and early 1930s was due to differences in municipal investments in child health education and poverty relief programs. While there were no public programs explicitly targeting fertility, the conservation of child life programs during the 1920s may have reduced fertility indirectly by educating individuals about behaviors and methods to reduce infant mortality. Additionally, charitable programs were implemented across municipalities as a way to alleviate the harmful effects of poverty. By changing the family incentives for children, these may have also affected fertility.

Determining a relationship between the public investments and fertility is relevant both for understanding the 1920s-1930s declines in U.S. fertility rates as well as for informing current policy. While the child health programs were not implemented with the explicit intent of lowering fertility, the programs advocated the importance of birth spacing and smaller families for improvements in child health outcomes (Woodbury 1925, Lathrop 1919). A relationship between the child health programs and fertility would indicate that people altered their behavior in response to the programs. Thus, the conservation of child life programs may have had consequences beyond their stated goals. As the child health programs were implemented in a period of distress over falling birth rates (Newmayer 1911; Meckel 1990, pp. 102), and, as indicated by Margaret Sanger, "contraceptive information has been classed with obscenity, pornography and abortion" (Sanger 1931), it is likely the programs veered away from explicit discussion of fertility. However, improvements in child mortality are closely related to fertility, so the baby-saving campaigns may have also translated to fewer births in the first place. Determining whether these programs affected fertility will shed

\footnotetext{
${ }^{3}$ TFR estimates for each census between 1800 and 1990 for the white population of the U.S. are available in "The White Population of the United States: 1790-1920 (Haines 2000, pg. 308). These TFR estimates are consistently above 3 .
} 
light on why the decline in urban fertility rates accelerated in the 1920s, and also on why fertility varied so much across U.S. cities. Regional variation in fertility has been a constant feature of the United States, and continues to be the case today (U.S. Bureau of the Census 2011: Section 2, Table 82). Understanding how investment in different types of public programs can influence fertility illustrates how conscious policy can lead to differences in fertility rates across otherwise similar areas.

\subsection{Historical U.S. fertility declines and a 1920s acceleration}

U.S. fertility was declining from at least as early as the mid to late 1800 s. Some have dated the beginning of American fertility decline to the start of the $19^{\text {th }}$ century (Hirschman 1994, David and Sanderson 1987), others arguing that the decline began in 1840 and that a broad reduction in marital fertility was not seen until the post-civil war period (Hacker 2003). The decline stopped in the late 1930s (U.S. Bureau of the Census 1975).

The reasons offered for the decline focus on changing demographic, religious, or economic circumstances. We do not attempt a full explanation of the different factors driving the fertility declines, instead we briefly overview some of the more important explanations to then determine their applicability to the 1920s. For a more complete overview, see Guinnane (2011).

One explanation for the U.S. fertility decline between the mid $-19^{\text {th }}$ and mid- $20^{\text {th }}$ centuries focuses on the emergence of a two child norm and a growing prevalence of fertility control among married women (David and Sanderson 1987). Hacker, however, suggests that the late $19^{\text {th }}$ century fertility decline is explained by the rising cost of land and a subsequent increasing average age at marriage (Hacker 2003). Macroeconomic circumstances may have also played a role: using individual-level U.S. data on the number of children-ever-born for cohorts between 1826 and 1960, Jones and Tertilt (2008) identify increases in income as driving the American fertility decline. The authors estimate that income as measured by occupation explains as much as 90 percent of the differences in fertility across time and between groups. The negative effect of income is thought to arise from an increasing opportunity cost of or, as argued by Gary Becker, increased investments in the quality of children (Becker 1960). On the other hand, economic recessions have consistently been shown to reduce fertility (Sobotka, Skirbekk, and Philipov 2011). Reductions in child mortality may have also influenced fertility. If individuals target for the number of children surviving to older ages, then reducing mortality will reduce fertility (Sah 1991; Eckstein, Mira, and Wolpin 1999; Doepke 2005). Conversely, reducing infant and child mortality reduces the expected 
cost of raising a surviving child (Barro and Becker 1989), potentially increasing fertility.

The above factors have limited power in explaining the acceleration of fertility decline in the 1920s, which is illustrated in Figure 1. This figure plots birth rates for women aged 15 and 44 between 1909 and 1950, and shows a clear acceleration in fertility decline in the 1920s. This decline accelerated in the urban areas as well. For cities over 100,000 persons, the ratio of children aged under 1 to women aged 15 to 44 declined from 75/1000 in 1910, to 72/1000 in 1920, and 57/1000 in 1930. Many of the explanations that work for earlier periods do not fit urban areas in the 1920s. First, there were no recessions - in urban areas, individuals were better off relative to the 1910s. Second, the proportion of married women between the ages of 15 and 44 increased from $60.5 \%$ in 1920 to $60.9 \%$ in 1930 , and the singulate mean age at marriage declined from 22.7 in 1920 to 21.2 in 1930 . Proximate factors such as fertility control and mortality decline remain candidate explanations accelerating fertility decline, but these may not be the whole story and we do not know what the ultimate factors behind these are.

\section{Figure 1: Native white fertility trends, 1909 to 1950}

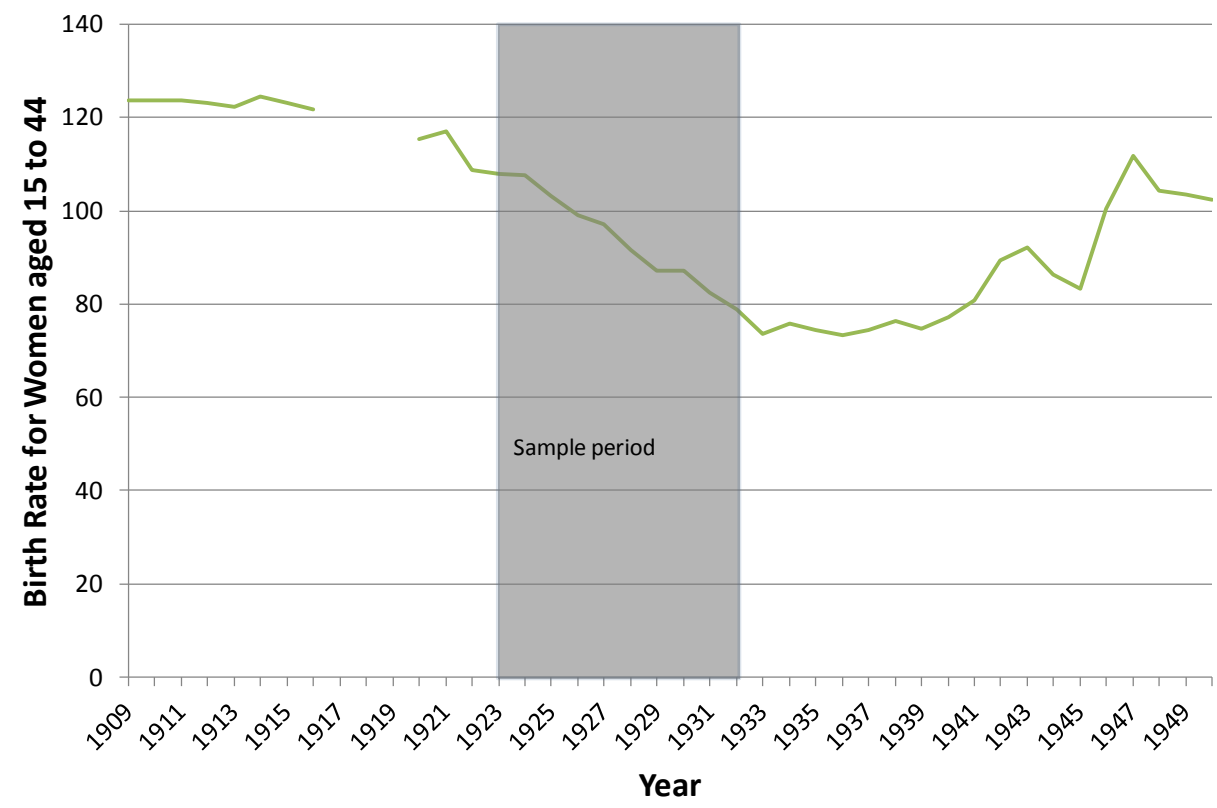

Notes: Source is Series B5-10 in the Historical Statistics of the United States, Colonial Times to 1970. 


\subsection{A 1920s fertility story}

The mystery of the 1920s fertility decline was first addressed by Richard Easterlin in 1961, and he argues that the decline was driven by a changing population composition; reductions in fertility among the foreign born and rural populations caused fertility to decline (Easterlin 1961). Changes in immigrant demographics, specifically the shift of immigrants from eastern and southern European countries to immigrants from western and northern European countries, changes in the foreign-born sex ratio, and an aging of the female foreign-born population reduced foreign-born fertility. Easterlin attributed one-third of the decline in total white fertility in the 1920s to the reduction in the fertility of the foreign-born white population (Easterlin 1961, pg. 878). It was for these reasons, Easterlin argues, that U.S. fertility declined in the relatively prosperous 1920s. However, while this may explain much of the overall trend of fertility in the U. S., it does less to explain why the fertility decline accelerated in the large urban areas of America. Rural-to-urban migration is unlikely to drive down urban fertility rates. And while some areas in the U.S. did have large foreign born populations, such as New York and Connecticut with over 26 percent of the state populations having been born overseas in 1920, many areas did not. Despite the tendency of the foreign born to concentrate in large urban areas, many cities over 100,000 persons in 1920 had foreign born populations under 20 percent. For these areas, changes in the foreign born population would not fully explain declining fertility.

We analyzed the contribution of a changing foreign-born population to changes in state-level fertility over 1920-1930. Table 1 separates state level fertility changes by the population groups "Native white," "Foreign born white," and "Colored," for states that were part of the 1920 Birth Registration Area (BRA) and had at least one city over 100,000 persons in 1920. Colored includes Asians, Pacific Islanders, Hispanics and other minority groups. ${ }^{4}$ Table 1 shows the almost universal decline in fertility across all population groups. In every state for which the calculations are possible, native white fertility declined between 1920 and 1930. With the exception of Kansas and Nebraska, this was also true for fertility among the colored population.

\footnotetext{
4 "Colored" includes different populations for different states. For California, Oregon, and Washington, "colored" is mostly Chinese and Japanese Americans, for most other states is it African Americans. In addition, the definition of "colored" changed between 1920 and 1930. In 1920, Mexicans were part of the "white" population, but in 1930 Mexicans were counted as part of the colored population. The effect of this is most evident in the California data, where the total fertility rate for the colored population declines from 5.3 in 1920 to an unrealistic 1.21 in 1930 . The statistic of 1.21 is primarily due to this changing definition combined with the substantial Mexican migration into California during the 1920s and a severe underreporting of Mexican births (U.S. Department of Commerce, 1922 pp. 4-5). The issue of the Mexican population statistics being differently enumerated between 1920 and 1930 should not influence the accuracy for the other states listed in Table 1.
} 
Fox \& Myrskylä: Urban fertility responses to local government programs

Table 1: Total fertility rate by population group in 1920 and 1930 BRA sample states

\begin{tabular}{llllllllll}
\hline State & \multicolumn{3}{c}{ Native white } & \multicolumn{3}{c}{ Foreign born } & \multicolumn{3}{c}{ Colored } \\
& $\mathbf{1 9 2 0}$ & $\mathbf{1 9 3 0}$ & Change & $\mathbf{1 9 2 0}$ & $\mathbf{1 9 3 0}$ & Change & $\mathbf{1 9 2 0}$ & $\mathbf{1 9 3 0}$ & Change \\
\hline 18 State avg. & 2.59 & 2.18 & -0.40 & 3.92 & 2.72 & -1.19 & 2.82 & 2.11 & -0.71 \\
California & 2.03 & 1.62 & -0.41 & 3.55 & 4.17 & 0.62 & 5.30 & 1.21 & -4.09 \\
Connecticut & 2.11 & 1.91 & -0.20 & 4.48 & 2.81 & -1.67 & 2.80 & 2.65 & -0.15 \\
Indiana & 2.74 & 2.36 & -0.38 & 4.40 & 3.46 & -0.94 & 1.95 & 1.82 & -0.13 \\
Kansas & 2.82 & 2.28 & -0.54 & 3.93 & 3.84 & -0.09 & 1.98 & 2.24 & 0.26 \\
Kentucky & 3.53 & 3.09 & -0.44 & 2.92 & 2.24 & -0.67 & 1.96 & 1.75 & -0.21 \\
Maryland & 2.86 & 2.17 & -0.69 & 3.98 & 2.40 & -1.58 & 3.06 & 2.61 & -0.45 \\
Massachusetts & 2.15 & 1.92 & -0.22 & 3.77 & 2.63 & -1.14 & 2.80 & 2.30 & -0.49 \\
Michigan & 2.92 & 2.50 & -0.42 & 4.33 & 2.93 & -1.41 & 2.22 & 2.07 & -0.15 \\
Minnesota & 2.81 & 2.35 & -0.46 & 3.67 & 2.63 & -1.04 & 3.01 & 2.92 & -0.09 \\
Nebraska & 2.88 & 2.46 & -0.42 & 3.87 & 3.03 & -0.84 & 2.25 & 3.03 & 0.79 \\
New York & 2.09 & 1.81 & -0.28 & 3.50 & 2.29 & -1.21 & 2.02 & 1.87 & -0.15 \\
Ohio & 2.45 & 2.17 & -0.28 & 4.00 & 2.67 & -1.33 & 2.20 & 2.03 & -0.16 \\
Oregon & 2.28 & 1.78 & -0.50 & 3.08 & 1.95 & -1.14 & 4.09 & 2.73 & -1.36 \\
Pennsylvania & 2.76 & 2.37 & -0.39 & 4.93 & 3.17 & -1.76 & 2.23 & 2.21 & -0.03 \\
Utah & 3.64 & 3.34 & -0.30 & 3.83 & 4.21 & 0.38 & 3.53 & 2.91 & -0.62 \\
Virginia & 3.64 & 2.81 & -0.83 & 3.83 & 2.86 & -0.97 & 3.53 & 2.98 & -0.55 \\
Washington & 2.34 & 1.82 & -0.52 & 2.89 & 2.31 & -0.57 & 5.37 & 3.36 & -2.01 \\
Wisconsin & 2.71 & 2.50 & -0.22 & 3.75 & 2.87 & -0.88 & 3.29 & 2.07 & -1.22 \\
\hline
\end{tabular}

Notes: The "Total Fertility Rate" is the sum of the age specific fertility rates for 5 year age groups for women between 15 and 44 . "Colored" includes Black, Asian, American Indian, and other minorities. For 1930, this category also includes "Mexican". Mexican births were severely underreported in 1930 and likely also in 1920. In 1920, Mexicans were generally enumerated under "White," however in 1930 they began to be enumerated under "Other." The large difference in the California TFR for the group of "Other" results from this under reporting and change in enumeration.

However, it is still not clear to what extent changes in fertility at the state level are due to changes in actual fertility or are due to changes in the relative group populations. To answer this, we decompose the fertility change into its parts using a stepwise replacement algorithm (Andreev, Shkolnikov and Begun 2002; Andreev and Shkolnikov 2012). We calculate the relative contributions of changes in fertility and changes in population structure to the overall change in state level fertility. These are given in Table 2. The table shows that changes in state level fertility between 1920 and 1930 were mostly driven by changes in fertility within the three different population groups, and not by shifts in their relative proportions. For those states in which changes in their proportions and age structure did play a role, this supports the Easterlin story of an aging of the female foreign born population out of the fertile age range. For example, population structure accounted for about 20 percent of the fertility decline in 
Connecticut. However, in most cases the relative population proportions and age structure did not account for a large proportion of the fertility decline. In half of the states (Indiana, Kansas, Kentucky, Maryland, Nebraska, Oregon, Utah, Virginia, and Washington), changes in native white fertility accounted for over 70 percent of the decline, while in another four (Wisconsin, Ohio, Minnesota, and California) it constituted over 50 percent. The analysis above does not account for rural versus urban fertility, so for those areas with large rural populations this may still be consistent with the Easterlin story. However, Table 2 indicates that it was fertility reductions within the population groups, not compositional changes, which drove the fertility decline in Birth Registration Areas during the 1920s.

Table 2: Fertility decomposition, 1920-1930

\begin{tabular}{lccccc}
\hline \multicolumn{5}{c}{ Changes in Total Fertility Rate from change in: } \\
State & $\begin{array}{c}\text { Native white } \\
\text { TFR }\end{array}$ & $\begin{array}{c}\text { Foreign born } \\
\text { white TFR }\end{array}$ & Colored TFR & $\begin{array}{c}\text { Population } \\
\text { structure }\end{array}$ & $\begin{array}{c}\text { Total change } \\
\text { in TFR }\end{array}$ \\
\hline 18 State Average & -0.367 & -0.148 & -0.038 & -0.042 & -0.595 \\
California & -0.317 & 0.060 & -0.292 & -0.042 & -0.591 \\
Connecticut & -0.134 & -0.516 & -0.004 & -0.158 & -0.812 \\
Indiana & -0.352 & -0.049 & -0.006 & -0.025 & -0.432 \\
Kansas & -0.499 & -0.007 & 0.011 & -0.037 & -0.532 \\
Kentucky & -0.398 & -0.004 & -0.023 & 0.025 & -0.400 \\
Maryland & -0.528 & -0.105 & -0.080 & -0.016 & -0.730 \\
Massachusetts & -0.152 & -0.350 & -0.007 & -0.100 & -0.609 \\
Michigan & -0.318 & -0.276 & -0.004 & -0.050 & -0.649 \\
Minnesota & -0.392 & -0.150 & -0.001 & -0.035 & -0.580 \\
Nebraska & -0.393 & -0.054 & 0.013 & -0.027 & -0.461 \\
New York & -0.189 & -0.378 & -0.007 & -0.051 & -0.624 \\
Ohio & -0.238 & -0.150 & -0.008 & -0.037 & -0.434 \\
Oregon & -0.447 & -0.094 & -0.019 & -0.013 & -0.574 \\
Pennsylvania & -0.308 & -0.284 & -0.003 & -0.101 & -0.695 \\
Utah & -0.731 & -0.076 & -0.038 & -0.024 & -0.869 \\
Virginia & -0.587 & -0.012 & -0.162 & -0.001 & -0.761 \\
Washington & -0.439 & -0.096 & -0.046 & -0.030 & -0.612 \\
Wisconsin & -0.184 & -0.119 & -0.008 & -0.028 & -0.340 \\
\hline & & & & & \\
\hline
\end{tabular}

Notes: TFR stands for "Total Fertility Rate," or the sum of the age specific fertility rates for 5 year age groups for women between 15 and 44.

"Colored" includes Black, Asian, American Indian, and other minorities. For 1930, this category also includes "Mexican". Mexican births were severely underreported in 1930 and likely also in 1920. In 1920, Mexicans were generally enumerated under "White," however in 1930 they began to be enumerated under "Other." The large difference in the California TFR for the group of "Other" results from this under reporting and change in enumeration. 


\section{Public programs and changes in fertility}

Compositional changes explain only a part of the 1920s' urban fertility decline; other factors need to be considered. Changing behaviors, values, and a response to economic incentives have been shown to be important in other periods, and may be responsible for some of the fertility change during the 1920s. We look at the interaction of these topics with local government programs, which has not been considered before. We evaluate whether local government programs, implemented to improve health and welfare, influenced fertility. Their role is important for any telling of a 1920s fertility story, despite these programs not explicitly targeting fertility.

Although there has been much work in the economics and demographic literature to understand how individuals make fertility decisions and how fertility trends have evolved over time, less work has been done to understand the relationship between U.S. government programs and local fertility. One exception finds that New Deal relief positively influenced fertility (Fishback, Haines, and Kantor 2007). Other work has looked at this relationship in developing countries and found, for instance, that cash transfers in Honduras increased fertility, but there was no distinguishable effect for similar programs in Mexico and Nicaragua (Stecklov et al. 2007).

During the 1920s there existed no large scale federal relief programs. Prior to the New Deal, poverty relief, public health, and other public goods were distributed at the state, municipal, and county levels. We focus on three different municipal level public programs - conservation of child life and its emphasis on public health education, charity for children and mothers, and outdoor care of poor - to examine whether investments in these influenced fertility across cities.

\subsection{Conservation of child life}

The full set of conservation of child life activities are enumerated in Table 3, however because the American Public Health Association opposed all forms of public health treatment activities (Upham 1922), it is likely that much of the spending distributed under conservation of child life was health education or informational related. "Publicity and educational" monies were typically used to distribute pamphlets or regular bulletins. As of 1921, 35 of the 68 cities over 100,000 persons in 1920 distributed some form of regular public health bulletin (U.S. Public Health Service 1923). Cities also held lectures or public health conferences, or sent physicians or nurses to schools, homes, or community gatherings. In these settings, they talked about the importance of breast feeding or use of clean formula, smaller families, hand washing, and proper nutrition during pregnancy. Many of the municipal health 
departments also had programs to inspect school children, where physicians or nurses conducted annual examinations and identified medical issues. In a few cities, smallpox vaccinations were given during these examinations, but more commonly the inspection was conducted and any defects found were referred to a private physician. Infant welfare stations were also set up in many of the different cities. Activities at these infant welfare stations varied considerably, but generally consisted of the supervision of expectant mothers and new infants, lectures, baby shows, and distribution of free literature (U.S. Public Health Service 1923).

\title{
Table 3: Health department budget expenses for conservation of child life
}

\author{
Medical work for school children \\ Sanitary inspection of school buildings \\ Inspection of school children by physicians \\ Inspection of school children by dentists \\ Work of nurses for school children and their families \\ General clinical and dispensary work for school children \\ Dental clinical and dispensary work for school children \\ Publicity and educational \\ Other medical work for school children
}

\section{Conservation of life of infants}

Supervision and regulation of midwives

Supervision and regulation of maternity hospitals and lying-in institutions

Physicians for mother and infant in private homes

Nurses for mother and infant in private homes

Clinics and dispensaries for mother and infant

Milk and pasteurizing stations

Publicity and educational

Other conservation of infant life

\section{Other conservation of child life}

Regulation and supervision of the boarding out of children

Regulation and supervision of orphan asylums and day nurseries

Regulation of the employment of children

Sundry expenses for conservation of child life

Source: Powers, Le Grand. (1912) Uniform Accounts as a Basis for Standard Forms: For Reporting Financial and Other Statistics of Health Departments. Government Printing Office, Washington D.C. 
The child health conservation programs during the 1920s were directed towards women and children with the goal of reducing infant and child mortality. However, they may have also had affected fertility by reducing child mortality and hence reducing incentives to replace or hoard children. On the other hand, the programs may have reduced the expected cost of raising a surviving child, potentially leading to higher fertility rates. Additionally, changing perceptions about long term health outcomes may also be a mechanism through which the child health conservation programs influenced fertility. If these programs resulted in the perception of healthier children with higher probabilities of survival until childbearing, then the incentive to increase fertility to insure against the failure of passing on parental genes would be decreased.

The child health programs may have also affected fertility directly. The programs advocated breastfeeding (e.g., U.S. Children's Bureau 1919), which would directly reduce fecundity in new mothers (Bongaarts 1987; John, Menken, and Chowdhury 1987). Additionally, these programs believed in the importance of smaller families as a way to reduce infant mortality (Duke 1915) and encouraged longer birth intervals for both maternal and child health (Dempsey 1919). Based on the above stated goals, it may be that maternal and infant hygiene clinics advocated the use of birth control to visiting women. However, we have so far been unable to find any evidence for a direction connection between the conservation of child life programs and the birth control debate which occurred simultaneously during the 1920s. This is not to say that birth control was not advocated to visiting women, but at the very least the surviving documents surveyed for this project are careful to avoid any mention of fertility control methods. Thus, while fertility control may have been a subtle factor used in tandem with the advice of longer birth intervals, it was beyond any of the stated goals of the programs in the different cities.

\subsection{Charity for children and mothers \& outdoor care of poor}

Relief programs targeted towards the poor in general, and single mothers and children in particular, may also help explain why fertility outcomes differed across areas. Charity for children and mothers combines spending on the two relief programs of mothers' pensions and charity directed towards children. Mothers' pensions were transfer payments given to widows with children, and grew out of an effort to improve the wellbeing of children and widowed mothers (Skocpol et al. 1993). Charity for children typically supported children residing in almshouses. Payments directed

towards poor mothers and children would reduce the individual cost of a child or future financial uncertainty and may increase fertility. Conversely, a social insurance program such as the outdoor care of poor programs can reduce reliance on family members 
during times of unemployment or old age, so may curtail the need for large families. Outdoor care of poor differed in its administration across cities, but typically involved relief to people who, due to unemployment, illness, accident, or other reasons, were temporarily dependent (Smith 1932, Lancaster 1937).

\section{Measuring local fertility}

In the fertility decomposition in Table 1, we used Total Fertility Rates (TFR), which were possible to calculate because the state-level data include births by age. Data at municipal or county levels are available only as total birth counts. Therefore we rely on the General Fertility Rate (GFR), calculated as the number of births divided by the number of women aged 15-44 for our municipal measure of fertility. ${ }^{5}$ In historical settings it is often difficult to obtain age-specific fertility rates required for the TFR, so many historical studies use GFR or a related index (Fishback, Haines, and Kantor 2007; Haines and Guest 2008; Jones and Tertilt 2008; David and Sanderson 1987). Although the GFR does not take age structure into account, its year-to-year changes are very similar to the year-to-year changes indicated by the TFR during the study period. Appendix A replicates our analysis using estimates of the TFR based on state or national-level fertility schedules and shows that the findings in this paper are not sensitive to the method of fertility rate calculation. Lastly, as the analysis in prior sections uses the TFR, we scaled the General Fertility down to be comparable by multiplying by 30 instead of by 1000 .

\section{U.S. municipal fertility, 1920 - 1932}

As shown in Table 1, fertility in BRAs exhibited substantial variation between areas. For example, in 1920, the TFR was as high as 3.6 in Virginia but only 2.4 in Oregon.

The BRAs consisted of about 60 percent of the U.S. in 1920, but grew throughout the decade so that by 1928,44 states were officially recording births. Figure 2 maps the BRA states in 1923 and 1928, as well as the corresponding sample cities (cities over 100,000 persons in 1920 that had joined the BRA prior to 1928).

In the early 1920s, the Southeast and Central U.S were largely unrepresented in the BRA, yet by 1928 only New Mexico, Nevada, South Dakota, and Texas chose not to

\footnotetext{
${ }^{5}$ It is possible to construct TFR estimates at the municipal or county level by assuming that fertility schedules in those places look the same as the state or national level. However, calculation of fertility in this manner introduces some level of error in the estimates, which may outweigh any advantage gained. Interested readers are referred to the appendix where this is undertaken.
} 
participate. Figure 3 plots the scaled GFR individually for four different BRA cities, as well as its average level in each year for all 64 sample cities. ${ }^{6}$ With the exception of a brief increase between 1923 and 1924, average fertility across the cities fell consistently between 1923 and 1932. The rates of decline, however, varied among cities. The four cities whose fertility levels are represented in Figure 3 are Fall River, MA, Camden, NJ, Los Angeles, CA, and San Francisco, CA, chosen for their differing fertility trajectories. Replacement level fertility is estimated to be approximately 2.3 during this period of time, and is indicated by the shaded area. ${ }^{7}$

\section{Figure 2: Changes in the Birth Registration Area from 1923}

\section{Legend}

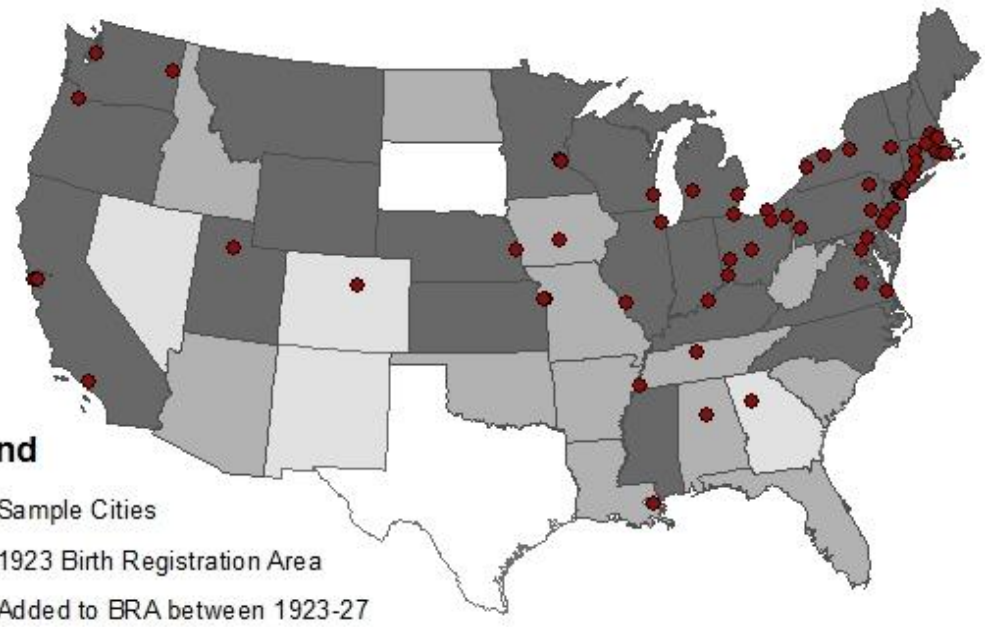

Added to BRA between 1928-29

Added to BRA between 1932-33

Notes: BRA stands for "Birth Registration Area," which consisted of the set of U.S. states recording birth information.

Camden, NJ and Fall River, MA started at similar position in the early 1920s, however by 1932 their fertility outcomes were very different. Aside from a slight increase in 1932, fertility in Fall River declined monotonically between 1923 and 1932,

\footnotetext{
${ }^{6}$ See the Appendix for a full list of each of the different cities included.

${ }^{7}$ Replacement level is approximated by $(1+\mathrm{SRB}) / \mathrm{p}(\mathrm{Am})$ where SRB is the sex ratio at birth. and $\mathrm{p}(\mathrm{Am})$ is the probability of surviving to the mean age at childbearing. The replacement level fertility of 2.3 for the U.S. is calculated with $\mathrm{SRB}=1.04$ and $\mathrm{p}(\mathrm{Am})=0.88$. 0.88 was the lifetable probability of a newborn girl surviving to age 30 in year 1933 (Source: Human Mortality Database).
} 
from almost 4 children per woman to below replacement level. The story differed in Camden, NJ, where fertility fluctuated above 3 children per woman with no clear trend over the study period. Fertility in Camden increased between 1923 and 1924, decreased in 1925 and 1926, and rose again in 1927 before falling through 1929, and then alternated between increasing and decreasing in 1930, 1931, and 1932. The second pair of cities in Figure 3 began the sample period at the bottom of the fertility distribution. While fertility in San Francisco decreased slowly throughout the 1920s and early 1930s, fertility in Los Angeles decreased rapidly. At the beginning of the decade, these cities were far apart in their fertility rates, but by the early 1930s, the gap had almost closed and both sat below a scaled GFR of 1.5. These were not the only cities that had reached such low fertility rates by the early 1930s. Portland, OR, and Kansas City, MO also had fertility rates below 1.5 during this year.

\section{Figure 3: Total fertility rate trends}

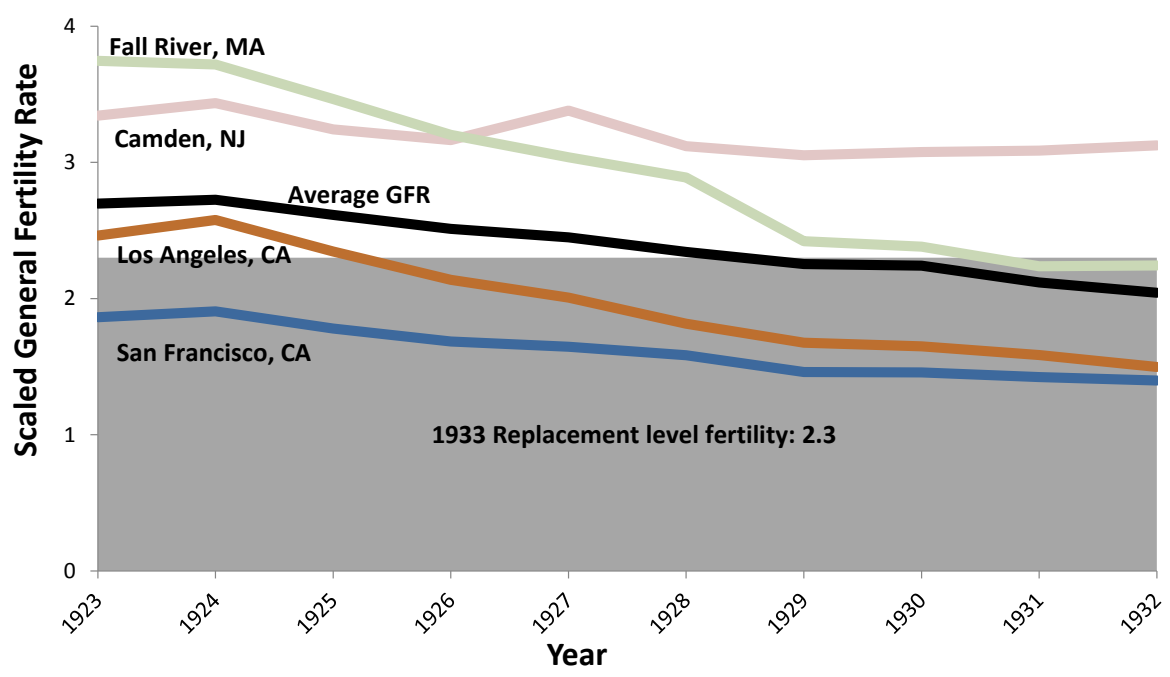

Notes: Fertility rates are the number of births per women aged 15 to 44 in each city, multiplied by 30 to make comparable to the TFR. Replacement level fertility is the level of fertility which would replace the population, accounting for sex ratios at birth and infant mortality.

Thus, some areas experienced much more rapid descents than others, even within the same geographic area. In some cases, the differences rivaled that of the often discussed urban/rural fertility difference. For example, in 1920 fertility in Fall River, MA was nearly 70 percent higher than fertility in San Francisco. 
These results show that the fertility decline varied across large U.S. cities during the 1920s. Many of the different explanations, outlined in Section 1, which have been shown to be important during other periods, are not entirely applicable to the period of the 1920s. Mean age at marriage was declining and urban economic outcomes were improving. For some U.S. urban areas, the Easterlin argument regarding the shift of the immigrant population may however be important. We propose and empirically test the claim that the programs to improve poor health and economic outcomes also played an important role in the 1920 s fertility decline.

\section{Data}

We estimate the relationship between public program investments and changes in fertility for a set of American municipalities with populations over 100,000 in 1920 and that were part of the BRA. The period under consideration is 1923-1932, chosen both for data availability reasons and to eliminate the effect of New Deal programs enacted after 1932. Information on the amount of spending distributed to these programs is obtained from the Financial Statistics of Cities volumes (U.S. Department of Commerce 1925-1936). These volumes also contain data regarding city expenditures on sanitation, health, and education. Per capita summary statistics adjusted to 2011 dollars for each of the spending variables are given in the top panel of Table 4. Population data by age and race were collected from the Decennial Censuses and interpolated for the inter-census years.

The three municipal spending variables - conservation of child life, charity for children and mothers, and outdoor care of poor - are given under Municipal Health and Welfare Spending. Adjusted to 2011 dollars, an average city in the dataset spent $\$ 3.70$ per person on health programs for children, $\$ 5.60$ on charity for children and mothers and $\$ 13.78$ per person on outdoor care of poor. The size of the mean per capita outdoor care of poor spending is due to significant growth at the end of the period. As a response to the Great Contraction of 1929, many cities substantially increased outdoor care of poor spending in the early 1930s. Although spending on conservation of child life and charity for children and mothers also increased between 1923 and 1932, the increases were not as drastic at the end of the panel. In addition, for conservation of child life, every city in the panel contributed at least some level of spending every year. For outdoor care of poor and charity for children and mothers, however, some cities chose not participate in the programs. Twelve cities chose not to participate at all towards charity for children and mothers between 1923 and 1932, and another ten had periods of zero spending. For outdoor care of poor, between 1923 and 1932 every city in the panel spent some amount, however some cities did have periods with no 
spending. Kansas City, KS and Scranton, PA, for example, waited until 1928 and 1930 to start investing in outdoor care of poor. Between 1923 and 1932, seven cities had periods of zero spending in this category.

Table 4: $\quad$ Summary statistics

\begin{tabular}{|c|c|c|c|c|}
\hline Variable & Mean & $\begin{array}{c}\text { Std. } \\
\text { Deviation }\end{array}$ & Min & Max \\
\hline Scaled GFR & 2.39 & 0.42 & 1.40 & 3.75 \\
\hline Infant mortality rate & 67.07 & 14.07 & 33.72 & 110.00 \\
\hline \multicolumn{5}{|l|}{ Municipal Spending Variables } \\
\hline \multicolumn{5}{|l|}{ Municipal health and welfare spending } \\
\hline Conservation of child life & $\$ 3.70$ & 2.34 & 0.08 & 13.71 \\
\hline Charity for children and mothers & 5.60 & 7.17 & 0.00 & 41.55 \\
\hline Outdoor care of poor & 13.78 & 27.74 & 0.00 & 234.72 \\
\hline Other health & 11.55 & 7.01 & 1.55 & 42.62 \\
\hline \multicolumn{5}{|l|}{ Other municipal cost payments } \\
\hline Sanitation & $\$ 36.89$ & 18.06 & 8.85 & 111.66 \\
\hline Hospitals & 11.48 & 12.65 & 0.00 & 99.96 \\
\hline Schools and libraries & 215.99 & 55.26 & 86.87 & 416.92 \\
\hline \multicolumn{5}{|l|}{ Personal income/Economic variables } \\
\hline Manufacturing wages per worker & $\$ 17,154.89$ & $2,295.19$ & $11,396.48$ & $26,438.66$ \\
\hline Proportion adults in manufacturing & 0.184 & 0.10 & 0.02 & 0.51 \\
\hline Population proportion filing taxes & 0.066 & 0.031 & 0.012 & 0.235 \\
\hline \multicolumn{5}{|l|}{ Municipal demographics } \\
\hline Proportion in city female \& aged $15-44$ & 0.259 & 0.012 & 0.237 & 0.304 \\
\hline Proportion black female \& aged 15-44 & 0.081 & 0.101 & 0.001 & 0.443 \\
\hline Proportion foreign born female \& age $15-44$ & 0.170 & 0.104 & 0.006 & 0.465 \\
\hline \multicolumn{5}{|l|}{ For persons over 10} \\
\hline Proportion illiterate & 0.033 & 0.018 & 0.006 & 0.097 \\
\hline \multicolumn{5}{|l|}{ County demographics } \\
\hline Proportion of women over age 15 married & 0.573 & 0.039 & 0.474 & 0.677 \\
\hline $\begin{array}{l}\text { Church membership proportion Roman } \\
\text { Catholic }\end{array}$ & 0.457 & 0.185 & 0.037 & 0.765 \\
\hline Population per square mile & $2,897.86$ & $4,738.78$ & 82.03 & $24,140.80$ \\
\hline
\end{tabular}

Notes: Government expenditures are per 100 persons and adjusted to 2011 dollars. Population figures are determined from the decennial censuses and interpolated.

Scaled GFR is a city's General Fertility Rate, scaled to match the Total Fertility Rate scale. Infant mortality rate is the number of infant deaths per 1000 live births. 
Additional municipal spending data from the Financial Statistics of Cities volumes includes that for other health, sanitation, hospitals, and schools and libraries. Provision of public goods such as sanitation and schools and libraries may be correlated with the provision of other public goods, such as conservation of child life, and fertility. This is especially true with spending on education, because the department of education oversaw the medical inspections of school children in a few cities (U.S. Public Health Service 1923).

Other data, in addition to that collected from the Financial Statistics of Cities volumes, includes information on income and wealth in the different cities. Personal income information is unavailable at the city level prior to 1940 , so we use average annual earnings from the manufacturing sector as a proxy. These are obtained from the Biannual Census of Manufactures volumes (U.S. Department of Commerce 19261936). ${ }^{8}$ Using manufacturing wages in the different cities helps control for differences in economic conditions that may confound the relationship between investments in the different programs of interest and fertility. This may be especially important in the case of outdoor care of poor, as cities may have responded to poor economic conditions by increasing spending. The average manufacturing wages adjusted to 2011 dollars in Table 4 were about $\$ 17,200$. To control for differences in the distribution of income, an additional measure of the number of tax returns filed in a year was collected from a series published by the U.S. Bureau of Internal Revenue (U.S. Bureau of Internal Revenue 1923-1932). This gives the number of jointly filing couples in each city with incomes above $\$ 5,000$ and individual filers with incomes over $\$ 2,000$ (respectively about $\$ 126,000$ and $\$ 50,000$ in 2011 dollars using contemporary standard of living values). Typically only about 6.5 percent of the population in the different cities filed taxes. The city with the highest proportion of filers was Los Angeles, with over a fifth of its population filing returns in 1923.

The demographics of a city are also possibly correlated with both public health and poverty relief spending, and fertility. The foreign born population generally had higher fertility than the native population, and also experienced worse health and economic outcomes (Duke 1915; Dempsey, 1919; Hughes 1923). In addition, since almost all births occurred within the institution of marriage, areas with higher proportions of married people would have higher levels of fertility. To control for changes in the population structure and other possible confounding demographic variables, municipal demographics for women of childbearing age were collected from the decennial censuses (U.S. Bureau of the Census 1921; 1931; 1942) and interpolated for the intercensus years. These include information on population density, the proportion over age

\footnotetext{
${ }^{8}$ For the odd numbered years we use a weighted interpolation between the closest even numbered years, using state per capita income as the weights. See Appendix C for details.
} 
15 married, minority concentrations for women between the ages of 15 and 44 , and literacy rates for individuals over the age of 10 .

Church membership data is also included for the county-level proportion of individuals who belonged to the Roman Catholic Church. Moehling and Thomasson (2012) find that Roman Catholic Church membership negatively influenced state-level participation in the Sheppard-Towner Act, a federal public health education bill aimed at educating individuals in small cities and rural areas. If these policies also played out at the city level, and Roman Catholics have different fertility than other religious groups, then failure to control for the religious composition of a city will bias the coefficient estimates. In addition, the Roman Catholic Church was by far the largest church for the majority of this period, so this provides a good index for whether other religious groups were becoming a larger part of a city's social structure. This ratio is calculated for each county by dividing the total number of church members in 1916, 1926, and 1936 by the number of Roman Catholic Church members and interpolating. This data is obtained from the 1916, 1926, and 1936 censuses of religious bodies (U.S. Bureau of the Census 1919; 1930; 1941).

\section{Model and estimation}

There is likely selection between the extent to which cities chose to participate in the different public programs and their level of fertility. Cities with high mortality and fertility may have chosen to invest more in public programs, or there may have existed a more complicated intersection of culture and beliefs affecting both the levels of fertility and the extent to which investments in conservation of child life and poor relief were made. It is possible to control for higher levels of mortality affecting both spending and fertility, but differences in culture and beliefs, especially at local levels, are more difficult to measure. Thus it is important to control for unobserved factors that potentially influence both fertility and spending on public programs in the different municipalities. Even controlling for city-level fixed effects, this selection could bias the relationship between public investments and fertility. For instance, cities experiencing a positive fertility shock in year $t$ may choose to spend more on conservation of child life programs in year $t+1$. This could then lead to a negative change in fertility and a positive change in conservation of child life spending between years $t$ and $t+1$. Table 5 presents estimates to check whether a change in fertility led to higher levels in spending for conservation of child life, outdoor care of poor, or charity for children and mothers. 
Table 5: $\quad$ Explaining spending with fertility

\begin{tabular}{lccc}
\hline Dependent var: & $\begin{array}{c}\text { Conservation of } \\
\text { child life spending }\end{array}$ & $\begin{array}{c}\text { Outdoor care of } \\
\text { poor spending }\end{array}$ & $\begin{array}{c}\text { Charity for children } \\
\text { and mothers }\end{array}$ \\
\hline Prior year scaled GFR & 0.0144 & $-0.259^{\star *}$ & -0.0165 \\
& 0.009 & $(0.087)$ & $(0.016)$ \\
Constant & -0.0090 & $0.7318^{\star *}$ & $0.0847+$ \\
City fixed effects & $(0.024)$ & $(0.236)$ & $(0.044)$ \\
Year fixed effects & $\mathrm{Y}$ & $\mathrm{Y}$ & $\mathrm{Y}$ \\
Observations & $\mathrm{Y}$ & $\mathrm{Y}$ & $\mathrm{Y}$ \\
Within R-squared & 486 & 486 & 486 \\
\hline
\end{tabular}

Notes: Scaled GFR is a city's General Fertility Rate, scaled to match the Total Fertility Rate scale.

Robust standard errors in parentheses. ${ }^{* *} p<0.01,{ }^{*} p<0.05,+p<0.1$. Government expenditures are per 100 persons and adjusted to 2011 dollars.

After controlling for spatial and temporal effects, prior year fertility is not significantly related to changes in spending for either conservation of child life or charity for children and mothers. Only for outdoor care of poor spending is the coefficient statistically different from zero. However, inclusion of the economic variables controlling for average annual manufacturing wages and the proportion of adults in manufacturing eliminates this statistical significance. Because variables are left out of the estimates presented in Table 5, these are not proof that changes in fertility in one year did not lead to changes in spending in the next. However, it is reassuring that after controlling for city and year fixed effects, a significant relationship does not remain. Although the existence of spending is likely associated with higher fertility levels in the different cities, year-to-year changes in spending are more plausibly exogenous. Thus, assuming that these unobserved factors that vary jointly with fertility and expenditures are not trending through time, it is possible to identify the relationship between these public programs and fertility using within city variation. Exploiting the panel structure of the data, we utilize this within variation through the use of a fixed effects model, defined below. Before presenting the model we discuss the appropriate lag structure.

The average waiting time until pregnancy is in the range of 244 weeks (Bongaarts 1978) and the length of time between conception and birth is about 40 weeks. Thus examining the effect on fertility for child health or poverty relief programs will require at least a one year lag. For the child health programs, it may have taken some time to disseminate information. Additionally, the programs may have affected fertility through birth spacing. A longer lag between expenditures and fertility changes is probably most 
appropriate for finding an effect. Thus we use a lag of two years. ${ }^{9}$ Any effect from the poverty relief programs on fertility is more likely to have an immediate effect. For these, a one year lag between expenditures and fertility is probably the most appropriate. We thus estimate the following model:

$$
\begin{aligned}
\widehat{G F R_{l, t}}= & \beta_{1} C C L_{i, t-2}+\beta_{2} C C M_{i, t-1}+\beta_{3} O C P_{i, t-1}+\beta_{4} I M R_{i, t-1} \\
& +\sum_{j=1}^{J} \delta_{j} X_{j, i, t-1}+\gamma_{1} C_{i}+\gamma_{2} Y_{t}+\epsilon_{i, t}
\end{aligned}
$$

The dependent variable is the General Fertility Rate, $\widehat{G F R_{l, t}}$, in city $i$ and year $t$. The independent variable, $C C L_{i, t-2}$, is the second lag of conservation of child life spending. The choice of only a second lag is based on considerations partly theoretical, as outlined above, and partly statistical. Statistically, the inclusion of the first lag of conservation of child life spending is neither economically not statistically significant, and does not affect the coefficient of the second lag. Theoretically, the educational nature of the conservation of child life programs meant that the activities engaged in under this spending likely took longer to percolate throughout a city than the welfare and poor relief payments of the other public programs studied here. Thus, for reasons of parsimony, we have included only the second lag of conservation of child life spending, and omitted the second lags of all other independent variables. For results from a model including the full distributed lag structure, please refer to the appendix.

$C C M_{i, t-1}$ is per capita spending on charity for children and mothers in city $i$ and year $t-1$ and $O C P_{i, t-1}$ is per capita spending on outdoor care of poor in city $i$ and year $t-1$. To control for mortality influences on public program spending and fertility, the lagged infant mortality rate, $I M R_{i, t-1}$ is included. $\sum_{j=1}^{J} \delta_{j} X_{j, i, t-1}$ is a set of $\mathrm{J}$ covariates that include the city demographic variables for the proportion of women between the age of 15 and 44, and the proportion of those women who were black or foreign born and between the ages of 15 and 44 . The proportion of illiterate individuals over the age of 10, the proportion of women between the ages of 15 and 44 and married, the population density of the surrounding county, and the proportion of individuals in that county belonging to the Roman Catholic Church are included as well, as is the amount of prior year per capita spending on sanitation, hospitals, education, and health other than child health. In addition, $X$ contains the income and income distribution measures and the proportion of adults working in manufacturing.

\footnotetext{
${ }^{9}$ Variations of the lag structure for the model in Section 6 are given in the Appendix.
} 
There may be still other factors influencing fertility. If these are jointly correlated with the spending variables of interest and fertility, then the model will not be identified. However, anything that is constant through time will be controlled for by the set of city fixed effects, represented in the model by $C_{i}$. In addition, controlling for a city-specific trend term, a state-specific trend term, or prior year fertility through an Arellano-Bond model does not significantly affect the coefficient estimates from equation (1). Estimates from these models are given in the appendix. Time-varying omitted variables can also confound estimates, so nationwide shocks common to all cities in the sample, due to changes in national optimism, shocks to national income, or other factors, are controlled for with period effects $Y_{t}$. Figure 3 suggests a common positive shock to fertility across many of the different cities in 1924, so these period effects may be important. Estimates from the model (1), as well as simpler models nested within the key model (1) are given in Table 6. The first column of Table 6 contains only the spending variables for conservation of child life, charity for children and mothers, and outdoor care of poor, as well as the city and year fixed effects. The second column includes all covariates, except the infant mortality rate (IMR). If the changes in fertility during the 1920 s were a response to changes in mortality, then inclusion of the infant mortality rate should diminish the effect of public program spending. Column 3 adds the IMR to the model while removing the economic variables controlling for average manufacturing wages and the proportion of adults working in manufacturing. Column 4 presents the coefficient estimates for the full model as given by equation (1). Comparison between columns 3 and 4 illustrate the importance of the economic variables in determining the significance, or lack thereof, for the different coefficient estimates. 
Table 6: Fixed effects regression results

\begin{tabular}{|c|c|c|c|c|}
\hline Dependent var: Scaled GFR & (1) & (2) & (3) & (4) \\
\hline \multicolumn{5}{|l|}{ Municipal health and welfare spending } \\
\hline \multirow[t]{2}{*}{ Conservation of child life (2 yr lag) } & -1.786 & $-1.93^{*}$ & $-2.653^{*}$ & $-1.939^{*}$ \\
\hline & $(1.478)$ & $(0.951)$ & $(1.081)$ & $(0.908)$ \\
\hline \multirow[t]{2}{*}{ Charity for children and mothers } & 0.288 & 0.437 & -0.058 & 0.443 \\
\hline & $(0.376)$ & $(0.291)$ & $(0.335)$ & $(0.289)$ \\
\hline \multirow[t]{2}{*}{ Outdoor care of poor } & $-0.283^{*}$ & -0.069 & $-0.204^{*}$ & -0.048 \\
\hline & $(0.113)$ & $(0.070)$ & $(0.079)$ & $(0.069)$ \\
\hline \multirow[t]{2}{*}{ Infant mortality rate } & & & $0.0032^{\star *}$ & $0.0029^{* *}$ \\
\hline & & & $(0.001)$ & $(0.001)$ \\
\hline \multicolumn{5}{|l|}{ Other spending variables } \\
\hline \multirow[t]{2}{*}{ Other health } & & $-0.896^{\star *}$ & $-0.704^{*}$ & $-0.946^{\star *}$ \\
\hline & & $(0.269)$ & $(0.311)$ & $(0.260)$ \\
\hline \multirow[t]{2}{*}{ Sanitation } & & 0.149 & 0.007 & 0.150 \\
\hline & & $(0.135)$ & $(0.200)$ & $(0.135)$ \\
\hline \multirow[t]{2}{*}{ Hospitals } & & 0.022 & $0.492+$ & -0.004 \\
\hline & & $(0.224)$ & $(0.290)$ & $(0.221)$ \\
\hline \multirow[t]{2}{*}{ Schools and libraries } & & $0.175^{\star *}$ & $0.148^{*}$ & $0.165^{\star *}$ \\
\hline & & $(0.052)$ & $(0.060)$ & $(0.049)$ \\
\hline \multicolumn{5}{|l|}{ Personal income/Economic } \\
\hline Manufacturing wages per & & $0.0042^{*}$ & & $0.0041^{*}$ \\
\hline 100 workers & & $(0.002)$ & & $(0.002)$ \\
\hline \multirow[t]{2}{*}{ Proportion adults in manufacturing } & & $2.359^{\star *}$ & & $2.369^{\star \star}$ \\
\hline & & $(0.463)$ & & $(0.448)$ \\
\hline \multirow[t]{2}{*}{ Population proportion filing taxes } & & $2.151^{*}$ & $3.284^{\star *}$ & $2.358^{*}$ \\
\hline & & $(0.985)$ & $(1.082)$ & $(0.977)$ \\
\hline \multicolumn{5}{|l|}{ Municipal } \\
\hline \multirow{3}{*}{ Proportion in city female \& aged $15-44$} & & -0.487 & 0.802 & -1.198 \\
\hline & & $(3.451)$ & (3.434) & (3.293) \\
\hline & & 2.058 & 1.294 & $2.589+$ \\
\hline \multirow[t]{2}{*}{ Proportion black female \& aged $15-44$} & & $(1.547)$ & $(1.963)$ & $(1.535)$ \\
\hline & & 1.092 & $2.647^{\star}$ & 1.014 \\
\hline \multirow{3}{*}{$\begin{array}{l}\text { Proportion foreign born female \& age } 15-44 \\
\text { Proportion over } 10 \text { and illiterate }\end{array}$} & & $(1.179)$ & $(1.308)$ & $(1.112)$ \\
\hline & & -3.012 & -0.696 & 3.593 \\
\hline & & (4.915) & $(5.324)$ & (4.659) \\
\hline \multicolumn{5}{|l|}{ Other } \\
\hline & & 2.870 & 1.158 & 2.767 \\
\hline \multirow[t]{2}{*}{ Proportion of women over age 15 married } & & $(2.267)$ & (3.022) & (2.206) \\
\hline & & $-2.388^{*}$ & -1.708 & $-2.444^{*}$ \\
\hline \multirow{3}{*}{$\begin{array}{l}\text { Proportion church membership Roman Catholic } \\
\text { County population density }\end{array}$} & & $(0.988)$ & 1.135 & $(0.952)$ \\
\hline & & $-0.00007^{\star *}$ & $-0.00005^{*}$ & $-0.00007^{\star *}$ \\
\hline & & $(0.00002)$ & $(0.00002)$ & $(0.00002)$ \\
\hline \multirow[t]{2}{*}{ Constant } & $2.636^{* *}$ & 0.417 & 1.306 & 0.500 \\
\hline & $(0.041)$ & $(1.777)$ & $(2.097)$ & $(1.662)$ \\
\hline City fixed effects & Y & $\mathrm{Y}$ & $\mathrm{Y}$ & $\mathrm{Y}$ \\
\hline Year fixed effects & $\mathrm{Y}$ & Y & $\mathrm{Y}$ & $\mathrm{Y}$ \\
\hline Observations & 486 & 486 & 486 & 486 \\
\hline Within R-squared & 0.731 & 0.833 & 0.793 & 0.839 \\
\hline
\end{tabular}

Notes: Robust standard errors in parentheses. ** $p<0.01,{ }^{*} p<0.05,+p<0.1$.

Scaled GFR is a city's General Fertility Rate, scaled to match the Total Fertility Rate scale. Unless otherwise noted, all variables are set at one year lags. Government expenditures are per 100 persons and adjusted to 2011 dollars. 
In the full model (4), of the key spending variables, only conservation of child life was significant statistically and economically, although spending on charity for children and mothers was also nearly statistically significant. In addition, alternative model specifications such as those in the appendix yield a positive and significant coefficient estimate for charity for children and mothers. Exclusion of the economic variables in Column 3 results in a coefficient estimate for charity and children and mothers close to zero. Because both average manufacturing wages and the proportion of workers in manufacturing are positively related to fertility, this suggests these variables are also negatively related to charity for children and mothers. Thus cities better off economically in a manufacturing sense spent less money on children in orphanages and mothers' pensions. This gives some clue into the positive coefficient estimate, and suggests that an increase in the number of poorer individuals led to both increases in municipal spending on almshouses and mothers' pensions as well as fertility. For outdoor care of poor, the opposite is true: its estimated coefficient is significant only with the exclusion of the economic variables. Thus outside of being a proxy for changing economic circumstances, spending on outdoor care of poor does not seem to be important in explaining fertility changes in the 1920s. Conversely, the coefficient on conservation of child life is significant in most versions of equation 1. Exclusion of the infant mortality rate only marginally affects the coefficient on conservation of child life spending, suggesting that the child health programs were not related to fertility through their effects on infant mortality.

Other variables with statistically significant coefficients include infant mortality, spending on other health, spending on schools and libraries, manufacturing wages, the proportion of adults in manufacturing, the proportion of the population that filed taxes, the proportion of the population female aged 15 to 44 and black, the proportion of church membership which was Roman Catholic, and the county population density. Although each of these relationships is interesting in their own light, their importance in the context of this paper is of secondary nature.

The positive relationships identified included spending on schools and libraries, manufacturing wages, proportion of adults in manufacturing, infant mortality, proportion of adults filing taxes, and the proportion of individuals who were between the ages of 15 and 44 and black females. These positive relationships are relatively consistent with what we might expect. Higher levels of infant mortality lead to hoarding and replacement of children. The positive relationship between the economic variables and fertility likely indicates fertility was pro-cyclical in cities during the 1920s, which is consistent with the recent empirical literature (Sobotka, Skirbekk, and Philipov 2011). That increases in public spending on schools and libraries are also positively associated with fertility is not entirely surprising, as increases in these public goods would reduce the expected cost of raising a child. Lastly, it was documented by organizations such as 
the Children's Bureau that African-American families had higher levels of fertility than native white families, which may explain the positive relationship between fertility and this demographic variable.

The negative relationships identified for the independent variables included spending on other health, the proportion of church membership which was Roman Catholic, and the population density of the surrounding county. Spending on "other health" was a combination of expenditures on health administration, vital statistics, prevention and treatment of diseases, and the regulation of food and dairy; and so increases in municipal health investments seem to have been followed by reductions in fertility. The same was true for the proportion of church membership which was Roman Catholic. The negative coefficient estimated by the model is most likely a result of the growing influence of the Baptist churches during this time. For areas that experienced changes in their religious compositions, this was often due to increases in the Baptist population at the expense of the Roman Catholics. The higher fertility of the Baptist followers would then explain this negative relationship. Lastly, cities located in more densely populated counties tended to have lower levels of fertility.

With regard to magnitudes, none of the coefficient estimates suggest that a single factor was the primary driver of the decline. The coefficient on IMR is economically significant, yet it explains only a small portion of the fertility decline. Across all cities, IMR declined from an average of 78.5 deaths per thousand live births in 1923 to 55.9 deaths per thousand live births in 1932. The average annual decline of IMR then being about 2.25, the estimated coefficient of 0.0029 implies a 0.0065 reduction in the overall General Fertility Rate (about $-0.24 \%$ from the 1923 average GFR of 2.74).

Comparing the magnitudes of the coefficients to each other, manufacturing wages would on average need to increase by 75 percent to create a 0.5 increase in the average GFR. Conversely, a 20 percent change in the proportion of people filing would generate about the same effect. Of the demographic variables, a 0.1 unit change in the proportion of individuals female, African American, and between the ages of 15 and 44, would tend to increase fertility by about 0.2 points. For education, a $\$ 60$ increase in spending is associated with a 0.1 increase in GFR. The largest annual change in education spending for any city in the sample between 1923 and 1932 was about $\$ 90$, so this level is fairly high relative to what cities were spending.

Table 7 converts the coefficients given in the in fourth column of Table 6 into the change necessary to deliver a 0.1 decrease in the scaled GFR. Coefficients significant at the 0.1 level are given in bold. Approximately $\$ 5.16$ dollars of per capita spending was associated with a reduction in municipal fertility rates by 0.1 . The average annual per capita conservation of child life expenditures was $\$ 3.70$, so the average level of spending was associated with an annual decline in the GFR of about 0.076. Applying this coefficient to the actual changes in fertility and spending, Figure 4 shows what this 
estimate indicates about the role of the conservation of child life expenditures for the 1920s fertility decline. Based on these estimates, Figure 4 constructs what fertility rates would have looked like if cities held all other forms of spending constant, but eliminated conservation of child life expenditures. Although this is an extrapolation from reality, it is helps illustrate the sense of relative importance of the conservation of child life spending. The predicted trend without conservation of child life spending plotted in Figure 4 is constructed by calculating the actual annual change, and then subtracting the estimated effect from spending in year $t-2$. This works out to:

$$
\Delta \widehat{G F R}_{t, t-1}^{n o C C L}=\Delta T F R_{t, t-1}-C C L_{t-2, t-3} * \beta_{1}
$$

\section{Figure 4: Changes in fertility due to conservation of child life spending}

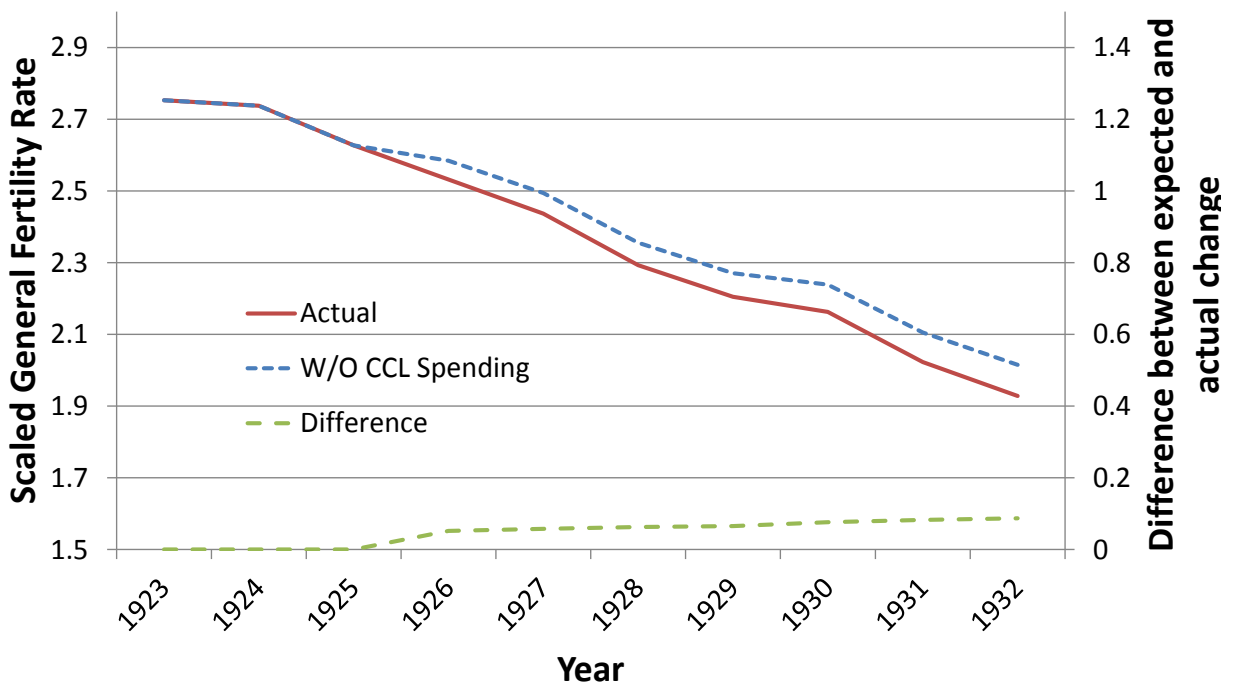

Notes: CCL stands for "Conservation of Child Life".

The predicted trend without CCL spending plotted is constructed by calculating the actual change in each year, then subtracting the estimated effect (Table 6, Column 4) from spending in year $t-2$. 
Table 7: Change necessary for 0.1 decrease in fertility

\begin{tabular}{lr}
\hline Municipal health and welfare spending & \\
Conservation of child life (2 yr lag) & $\$ 5.16$ \\
Charity for children and mothers & $\$ 22.55$ \\
Outdoor care of poor & $\$ 208.71$ \\
\hline Infant mortality rate & -34.483 \\
Other spending variables & \\
$\quad$ Other health spending & $\$ 10.57$ \\
Sanitation spending & $-\$ 66.48$ \\
Hospital spending & $\$ 2,703.21$ \\
Spending on schools and libraries & $-\$ 60.61$ \\
\hline Personal income/Economic outcome vars & \\
Manufacturing wages per worker & $-\$ 2,439.02$ \\
Proportion of adults in manufacturing & -0.0422 \\
Population proportion filing taxes & $-\mathbf{0 . 0 4 2 4}$ \\
\hline
\end{tabular}

Notes: Estimates are based off of the coefficients given in Table 6, Column 4. Unless otherwise noted, the relationships are between TFR hat and the 1 year lag of the different variables. Bolded values indicate a statistically significant relationship at the 0.1 level.

The estimate in Table 6 suggests that, if municipalities during the 1920s and early 1930s did not invest in the conservation of child life programs, fertility rates would have been about 5 percent higher. Alternatively, the conservation of child life programs explain about 10 percent of the change in fertility in 1920-1932. Variations in spending across areas also explain some of the city level variation. For cities in a state such as New Jersey, which invested heavily in the conservation of child life programs, the coefficient estimates potentially explain as much as 20 to 40 percent of the fertility decline for the different cities. Many of the cities in Ohio, on the other hand, invested less in these programs. For these areas, the coefficient estimates potentially explain only around 7 percent of the fertility decline that occurred.

The above analysis does not indicate that the conservation of child life programs, entered into by the different municipalities for the stated goals of infant and maternal preservation of life, were the sole or even the most important driver of fertility decline during the 1920s and early 1930s. For places such as Connecticut, New York, and other areas with high populations of foreign born, the Easterlin story of a changing immigrant composition may play an important role. For other areas, explanations such as those outlined in the sections above may be important as well. But based on estimates from a variety of specifications, investments in conservation of child life were significantly related to declines in fertility. Cities that invested in these programs, through perhaps 
their contribution to health, or perhaps through their advocacy of practices such as breast feeding, birth spacing, and smaller families, tended to experience more rapid declines in fertility.

\section{Conclusion}

Aside from the baby boom of the 1940s and 50s and the slow fertility increase starting in the $1970 \mathrm{~s},{ }^{10}$ fertility in the U.S. has been declining since the mid-1800s. A variety of reasons for this overall negative trend have been offered, likely because different reasons have proven to be important during different periods. During the $18^{\text {th }}$ Century, it was likely the increasing price of land and associated increase in the age of marriage (Hacker 2003). Increases in per capita income, and the opportunity costs and substitution effects that come with those increases, have also been shown important (Jones and Tertilt 2008). Fertility control has certainly played a role, as well as the numerous demographic shifts which have occurred over the history of the U.S. To these different explanations, we would like to offer support for the contributing factor of public policy decisions. We do not know if reducing fertility was a subtle, unstated goal of the conservation of child life programs administered in the different municipalities, but the presence of these programs were significantly related to the fertility declines that these areas experienced.

Some of the cities analyzed invested relatively heavily in these programs, while others invested relatively light in the years 1923-1932. Fertility patterns also varied strongly across areas on the same period, and this variation in fertility has continued to be the case in the U.S. These differences across areas are due to a multitude of cultural and economic factors, outside the scope of this study. For a fuller understanding of regional differences in fertility across the U.S., please see Lesthaeghe and Neidert (2006). We would like to point out, however, that differences in investment in certain types of public programs, specifically conservation of child life, potentially offer one additional reason for why different cities experienced different fertility outcomes in the 1920s and early 1930s. Although these programs were instituted as a means for reducing mortality and did not explicitly target fertility, it appears this was one of their effects.

\footnotetext{
${ }^{10}$ Myrskylä, Kohler, and Billari (2009) document recent increases in fertility rates for highly developed countries.
} 


\section{Acknowledgements}

We owe thanks to Price Fishback, Martha Bailey, Melissa Thomasson, Evan Roberts, Josh Goldstein, and Michael Haines, to several anonymous referees, and to seminar participants at the Lund University Centre for Economic Demography, Humboldt University, and Max Planck Institute for Demographic Research. Mikko Myrskylä was supported by the European Research Council grant 2013-StG-336475. 


\section{References}

Andreev, E.M. and Shkolnikov, V.M. (2012). An Excel spreadsheet for the decomposition of a difference between two values of an aggregate demographic measure by stepwise replacement running from young to old ages. Rostock: Max Planck Institute for Demographic Research (MPIDR Technical Report TR2012-002).

Andreev, E.M., Shkolnikov, V.M., and Begun, A.Z. (2002). Algorithm for decomposition of differences between aggregate demographic measures and its application to life expectancies, healthy life expectancies, parity-progression ratios and total fertility rates. Demographic Research 7(14): 499-522. doi:10.4054/DemRes.2002.7.14.

Barro, R.J. and Becker, G.S. (1989). Fertility Choice in a Model of Economic Growth. Econometrica 57(2): 481-501. doi:10.2307/1912563.

Becker, G.S. (1960). An economic analysis of fertility. In: National Bureau of Economic Research (ed.). Demographic and Economic Change in Developed Countries. Princeton: Princeton University Press: 209-240.

Becker, G.S. and Tomes, N. (1976). Child endowments and the quantity and quality of children. Journal of Political Economy 84(3): 143-162. doi:10.3386/w0123.

Bongaarts, J. (1978). A Framework for Analyzing the Proximate Determinants of Fertility. Population and Development Review 4(1): 105-132. doi:10.2307/ 1972149.

Bongaarts, J. (1987). The proximate determinants of fertility. Technology in Society 9(3-4): 243-260. doi:10.1016/0160-791X(87)90003-0.

David, P.A. and Sanderson, W.C. (1987). The Emergence of a Two-Child Norm among American Birth-Controllers. Population and Development Review 13(1): 1-41. doi:10.2307/1972119.

Dempsey, M.V. (1919). Infant mortality: Results of a field study in Brockton, MA based on births in one year. Washington D.C.: Government Printing Office.

Doepke, M. (2005). Child mortality and fertility decline: Does the Barro-Becker model fit the facts? Journal of Population Economics 18(2): 337-366. doi:10.1007/ s00148-004-0208-z.

Duke, E. (1915). Results of field study in Johnstown, PA based on births in one calendar year. Washington, D.C.: Government Printing Office. 
Easterlin, R.A. (1961). The American baby boom in historical perspective. The American Economic Review 51(5): 869-911.

Eckstein, Z., Mira, P., and Wolpin, K.I. (1999). A Quantitative Analysis of Swedish Fertility Dynamics: 1751-1990. Review of Economic Dynamics 2(1): 137-165. doi:10.1006/redy.1998.0041.

Fishback, P.V., Haines, M.R., and Kantor, S. (2007). Births, Deaths, and New Deal Relief during the Great Depression. Review of Economics and Statistics 89(1): 1-14. doi:10.1162/rest.89.1.1.

Guinnane, T.W. (2011). The Historical Fertility Transition: A Guide for Economists. Journal of Economic Literature 49(3): 589-614. doi:10.1257/jel.49.3.589.

Hacker, J.D. (2003). Rethinking the "early" decline of marital fertility in the united states. Demography 40(4): 605-620. doi:10.1353/dem.2003.0035.

Haines, M.R. (2000). The white population of the United States, 1790-1920. In: Haines, M.R. and Steckel, R.H. (eds.). A Population History of North America. New York: Cambridge University Press: 305-370.

Haines, M.R. and Guest, A.M. (2008). Fertility in New York state in the pre-civil war era. Demography 45(2): 345-361. doi:10.1353/dem.0.0009.

Hirschman, C. (1994). Why Fertility Changes. Annual Review of Sociology 20(1): 203233. doi:10.1146/annurev.so.20.080194.001223.

Hughes, E. (1923). Infant mortality: Results of field study in Gary, Ind., based on births in one year. Washington D.C.: Government Printing Office.

John, A.M., Menken, J.A., and Chowdhury, A.K.M.A. (1987). The Effects of Breastfeeding and Nutrition on Fecundability in Rural Bangladesh: A HazardsModel Analysis. Population Studies 41(3): 433-446. doi:10.1080/ 0032472031000142986.

Jones, L.E. and Tertilt, M. (2008). An economic history of fertility in the U.S.: 18261960. In: Rupert, P. (ed.). Frontiers of Family Economics. Emerald Group Pub.: $165-230$.

Lancaster, L.W. (1937). Government in rural America. New York: D. Van Nostrand Company.

Larry, E.J. and Michèle, T. (2008). An Economic History of Fertility in the United States: 1826?1960. In: Rupert, P. (ed.). Frontiers of Family Economics. Bingley, West Yorkshire: Emerald Group Publishing Limited: 165-230. 
Fox \& Myrskylä: Urban fertility responses to local government programs

Lathrop, J.C. (1919). Income and infant mortality. American Journal of Public Health 9(4): 270-274. doi:10.2105/AJPH.9.4.270.

Lesthaeghe, R.J. and Neidert, L. (2006). The Second Demographic Transition in the United States: Exception or Textbook Example? Population and Development Review 32(4): 669-698. doi:10.1111/j.1728-4457.2006.00146.x.

Meckel, R.A. (1990). Save the Babies: American Public Health Reform and the Prevention of Infant Mortality, 1850-1929. Ann Arbor: University of Michigan Press.

Moehling, C.M. and Thomasson, M.A. (2012). The Political Economy of Saving Mothers and Babies: The Politics of State Participation in the Sheppard-Towner Program. The Journal of Economic History 72(1): 75-103. doi:10.1017/S002205 0711002440.

Myrskylä, M., Kohler, H.-P., and Billari, F.C. (2009). Advances in development reverse fertility declines. Nature 460(7256): 741-743. doi:10.1038/nature08230.

Newmayer, S.W. (1911). The Warfare Against Infant Mortality. The ANNALS of the American Academy of Political and Social Science 37(2): 288-298. doi:10.1177/ 000271621103700224.

Sah, R.K. (1991). The Effects of Child Mortality Changes on Fertility Choice and Parental Welfare. Journal of Political Economy 99(3): 582-606. doi:10.1086/ 261768.

Sanger, M. (1931). The pro and con feature: Proposed federal legislation on birth control. Congressional Digest 10(4): 104-108.

Skocpol, T., Abend-Wein, M., Howard, C., and Lehmann, S.G. (1993). Women's Associations and the Enactment of Mothers' Pensions in the United States. The American Political Science Review 87(3): 686-701. doi:10.2307/2938744.

Smith, M.P. (1932). Trends in Municipal Administration of Public Welfare: 19001930. Social Forces 10(3): 371-377. doi:10.2307/2569677.

Sobotka, T., Skirbekk, V., and Philipov, D. (2011). Economic Recession and Fertility in the Developed World. Population and Development Review 37(2): 267-306. doi:10.1111/j.1728-4457.2011.00411.x.

Stecklov, G., Winters, P., Todd, J., and Regalia, F. (2007). Unintended effects of poverty programmes on childbearing in less developed countries: Experimental evidence from Latin America. Population Studies 61(2): 125-140. doi:10.1080/ 00324720701300396. 
U.S. Bureau of Internal Revenue (1923-19362). Statistics of Income. Washington, D.C.: Government Printing Office.

U.S. Bureau of the Census (1919). Religious bodies: 1916. Washington, D.C.: Government Printing Office.

U.S. Bureau of the Census (1921). Fourteenth census of the United States taken in the year 1920. Washington, D.C.: Government Printing Office.

U.S. Bureau of the Census (1930). Religious bodies: 1926. Washington, D.C.: Government Printing Office.

U.S. Bureau of the Census (1931). Fifteenth census of the United States taken in the year 1930. Washington, D.C.: Government Printing Office.

U.S. Bureau of the Census (1941). Religious bodies: 1936. Washington, D.C.: Government Printing Office.

U.S. Bureau of the Census (1942). Sixteenth census of the United States: 1940. Washington, D.C.: Government Printing Office.

U.S. Bureau of the Census (1975). Historical statistics of the United States, colonial times to 1970, bicentennial edition. Washington, D.C.: Government Printing Office.

U.S. Bureau of the Census (2011). Statistical abstract of the United States: 2012 (131st edition). Washington, D.C.: Government Printing Office.

U.S. Children's Bureau (1919). Our Children. Film.

U.S. Department of Commerce (1922-1923). Birth statistics for the birth registration area of the United States. Washington, D.C.: Government Printing Office.

U.S. Department of Commerce (1924-1934). Birth, stillbirth and infant mortality statistics. Washington, D.C.: Government Printing Office.

U.S. Department of Commerce (1925-1936). Financial statistics of cities. Washington, D.C.: Government Printing Office.

U.S. Department of Commerce (1926-1936). Biennial census of manufactures. Washington, D.C.: Government Printing Office.

U.S. Public Health Service (1923). Public health bulletin 136: Report of the committee on municipal health department practice. Washington, D.C.: Government Printing Office. 
Fox \& Myrskylä: Urban fertility responses to local government programs

Williamson, S.H. (2015). Seven ways to compute the relative value of a U.S. dollar amount, 1774 to present [electronic resource]. MeasuringWorth. http://www.measuringworth.com/uscompare/

Woodbury, R.M. (1925). Causal Factors in Infant Mortality, Children's Bureau Publication No. 142. Washington, D.C.: Government Printing Office. 


\section{Appendices}

\section{A. Alternative measures of municipal fertility rates}

The primary text measures municipal fertility using a scaled version of the General Fertility Rate. This is the simple ratio of the total number of births to the number of women between the ages of 15 and 44 , multiplied by 30 . Normally this ratio is multiplied by 1000; however, we wished it to be on the same scale as the Total Fertility Rate (TFR). When the data allows, use of this TFR is preferable, as it allows for controlling of the age structure of fertility. which may vary across areas.

Although births by age are not available at the city level during the sample period, it is possible to construct municipal TFRs using the age structure of the state or the overall Birth Registration Area (BRA) in which each city resides. We name the TFR that uses the age structure of the state in which each city resides the TFR ${ }^{*}$, and the TFR that uses the age structure of the overall Birth Registration Area the $\widehat{T F R}$. We begin with the description of the latter.

In order to calculate $\widehat{T F R}$ for each city in the sample, we estimate the municipal age specific birth rates using the BRA as a whole. The age-specific birth rates are defined as ${ }_{n} F_{x}^{B R A, t}$, where $n$ is the length of the age group (5 years), $x$ is the age group (15 to 19,20 to 24,25 to 29,30 to 34,35 to 39 , or 40 to 44 ), $B R A$ indicates that this is for the entire Birth Registration Area, and $t$ is the time period reference. Because of the expansion of the BRA between 1920 and 1933, different years will see different sets of participating states. See Table $\mathrm{C} 1$ for an accounting of BRA entry for each of the different states. We express the age specific birth rate for those areas participating in the BRA as:

$$
{ }_{n} F_{x}^{B R A, t}=\frac{{ }_{n} B_{x}^{B R A, t}}{{ }_{n} P_{x}^{B R A, t}}
$$

${ }_{n} B_{x}^{B R A, t}$ is the number of births in a specific age group and ${ }_{n} P_{x}^{B R A, t}$ is the female population within that age group. These age specific fertility rates are then used to create a proportion ${ }_{n} \lambda_{x}^{B R A}$, where

$$
{ }_{n} \lambda{ }_{x}^{B R A}=\frac{{ }_{n}^{B} B_{x}^{B R A . t}}{\sum_{y=\alpha}^{\beta-n}{ }_{n} F_{y}^{B R A, t}}
$$


Here, $\alpha$ is the minimum age at childbearing, which we set at 15 , and $\beta$ is the maximum age at childbearing, which we set at 44 . The age-specific births for each city $i$ are then:

$$
{ }_{n} \widehat{B}_{\mathrm{x}}^{\mathrm{i}, \mathrm{t}}={ }_{n} \mathrm{~B}^{\mathrm{i}, \mathrm{t}} *{ }_{n} \lambda_{\mathrm{x}}^{\mathrm{BRA}, \mathrm{t}}
$$

$T \hat{F} R^{i, t}$ is then:

$$
\widehat{T F R}^{i, t}=n * \sum_{x=\alpha}^{\beta-n} \frac{{ }_{n} \hat{B}_{x}^{i, t}}{{ }_{n} P_{x}^{i, t}}
$$

The second calculation of the municipal TFRs uses a finer level of detail. For $T F R^{*}$, the state-level age-specific fertility rates are used in place of rates from the entire BRA. Thus, the age-specific birth counts ${ }_{n} \hat{B}_{x}^{i, t}$ are calculated using a $\lambda$ calculated at the state level. Specifically, ${ }_{n} \hat{B}_{x}^{i, t}={ }_{n} B^{i, t} *{ }_{n} \lambda_{x}^{s, t}$, where $s$ is the state in which city $i$ lies. The age-specific birth counts are then used to estimate $T F R^{*}$. Estimates from the models substituting $T F R^{*}$ and $\widehat{T F R}$ for the scaled General Fertility Rate as presented in Section 6 are given in Table A1.

For both models, the coefficient estimates are very similar to those given in Table 6 , suggesting that it does not make much of a difference which of the three dependent variables is used in the model given in Section 6. 
Table A1: New dependent variables results

\begin{tabular}{|c|c|c|}
\hline Dependent var: & TFR hat & TFR $^{\star}$ \\
\hline \multicolumn{3}{|l|}{ Municipal health and welfare spending } \\
\hline \multirow[t]{2}{*}{ Conservation of child life (2 yr lag) } & $-1.977^{\star}$ & $-1.961^{*}$ \\
\hline & $(0.889)$ & $(0.899)$ \\
\hline \multirow[t]{2}{*}{ Charity for children and mothers } & 0.445 & 0.457 \\
\hline & $(0.278)$ & $(0.281)$ \\
\hline \multirow[t]{2}{*}{ Outdoor care of poor } & -0.041 & -0.042 \\
\hline & $(0.064)$ & $(0.064)$ \\
\hline \multirow[t]{2}{*}{ Infant mortality rate } & $0.0028^{\star *}$ & $0.0028^{\star *}$ \\
\hline & $(0.001)$ & $(0.001)$ \\
\hline \multicolumn{3}{|l|}{ Other spending variables } \\
\hline \multirow[t]{2}{*}{ Other health } & $-0.909^{* *}$ & $-0.905^{\star *}$ \\
\hline & $(0.247)$ & $(0.247)$ \\
\hline \multirow[t]{2}{*}{ Sanitation } & 0.140 & 0.148 \\
\hline & $(0.136)$ & $(0.137)$ \\
\hline \multirow[t]{2}{*}{ Hospitals } & -0.013 & -0.020 \\
\hline & $(0.208)$ & $(0.210)$ \\
\hline \multirow[t]{2}{*}{ Schools and libraries } & $0.1658^{* *}$ & $0.166^{* *}$ \\
\hline & $(0.048)$ & $(0.049)$ \\
\hline \multicolumn{3}{|l|}{ Personal income/Economic } \\
\hline Manufacturing wages per & $0.0039^{*}$ & $0.0039^{*}$ \\
\hline 100 workers & $(0.002)$ & $(0.002)$ \\
\hline \multirow[t]{2}{*}{ Proportion adults in manufacturing } & $2.354^{\star *}$ & $2.359^{* *}$ \\
\hline & $(0.429)$ & $(0.426)$ \\
\hline \multirow[t]{2}{*}{ Population proportion filing taxes } & $2.251^{*}$ & $2.261^{*}$ \\
\hline & $(0.932)$ & $(0.937)$ \\
\hline \multicolumn{3}{|l|}{ Municipal } \\
\hline \multicolumn{3}{|l|}{ For women aged 15 to 44} \\
\hline \multirow[t]{2}{*}{ Proportion in a city } & -1.521 & -1.360 \\
\hline & $(3.211)$ & $(3.226)$ \\
\hline \multirow[t]{2}{*}{ Proportion black } & $2.768+$ & $2.881+$ \\
\hline & $(1.488)$ & $(1.488)$ \\
\hline \multirow[t]{2}{*}{ Proportion foreign born } & 0.764 & 0.763 \\
\hline & $(1.129)$ & $(1.147)$ \\
\hline \multirow[t]{2}{*}{ Proportion over 10 and illiterate } & -3.539 & -4.564 \\
\hline & $(4.511)$ & $(4.516)$ \\
\hline \multicolumn{3}{|l|}{ Other } \\
\hline \multirow{2}{*}{ Proportion of women over age 15 married } & 2.101 & 1.946 \\
\hline & $(2.241)$ & $(2.215)$ \\
\hline \multirow{2}{*}{ Church membership proportion Roman Catholic } & $-2.461^{* *}$ & $-2.449^{* *}$ \\
\hline & $(0.904)$ & $(0.906)$ \\
\hline \multirow[t]{2}{*}{ County population density } & $-0.000071^{* *}$ & $-0.000072^{* *}$ \\
\hline & $(0.00002)$ & $(0.00002)$ \\
\hline Constant & 0.946 & 1.008 \\
\hline & $(1.648)$ & $(1.611)$ \\
\hline City fixed effects & $\mathrm{Y}$ & $\mathrm{Y}$ \\
\hline Year fixed effects & Y & Y \\
\hline Observations & 486 & 486 \\
\hline Within R-squared & 0.830 & 0.821 \\
\hline
\end{tabular}

Notes: Robust standard errors in parentheses.

${ }^{* *} p<0.01,{ }^{*} p<0.05,+p<0.1$. TFR hat is the total fertility rate estimating using the BRA age-specific fertility rates. TFR is the total fertility rate estimated using state level age-specific fertility rates. Unless otherwise stated, all variables are set at one year lags. Government expenditures are per 100 persons and adjusted to 2011 dollars. 


\section{B. Additional sensitivity analyses}

This section goes through other alternative models to identify the effect of the different public programs. The model given in Section 6 is changed in four different ways. The first is by controlling for city-specific trends, the second by controlling for state-specific trends, the third by adding a full set of distributed lags, and the fourth by estimating an Arellano-Bond model.

\section{B.1 Including city-specific trends}

The first robustness checks the model's sensitivity to the inclusion of city-specific trends. The variable $g_{i} * t$ is added to the model in Section 6 to control for the different fertility trends that may vary across cities. Controlling for the trend in this manner differs from using an overall year fixed effect or linear trend for the sample. Inclusion of the $g_{i} * t$ variable controls for the average trend in fertility between 1923 and 1932 for each of the different cities. Identification of the model coefficients thus comes off of the deviations from these average trends. Because the city-specific-trend variable controls for all city-specific linear trends, interpolated variables from the decennial censuses must be excluded from the model. These include the municipal demographic variables controlling for the proportion of women in a city between the ages of 15 and 44 in a city overall, black, or foreign born, as well as the proportion of individuals illiterate and over the age of 10. It also excludes the proportion of women between the ages of 15 and 44 and married, the proportion of church membership which is Roman Catholic, and the population density of the surrounding county. Estimates from the model including this random trend variable are given in Table B1. Column 1 includes only the spending variables of interest, city and year fixed effects, and the random trend variable. Column 2 includes the full set of covariates, less those which are linear in time.

From Column 2, inclusion of the city specific trends does attenuate the coefficient on conservation of child life spending. However, the estimated relationship is still economically and statistically significant. From this model, it is estimated that about $\$ 6.34$ dollars of per capita public health education spending are associated with reducing fertility by 0.1 points. Charity for children and mothers in this specification has a coefficient estimated as positive and statistically significant at the 10 percent level. The coefficients on spending on schools and libraries and the proportion of adults in manufacturing are no longer statistically significant, and all statistically significant coefficients have been attenuated relative to their values in Table 6 . The coefficient on outdoor care of poor continues to be estimated as not significantly affecting fertility in 
the different cities once manufacturing wages and the proportion of adults in manufacturing are included in the model. Thus, the overall conclusions made based on the results in Table 6 continue to hold.

\section{B.2 Including state-specific trends}

The second robustness check substitutes the city-specific trends of the subsection above with a set of state-specific trends. Because many of the cities reside within the same state, it may be that these areas experience similar fertility trajectories. Generally, when there exists this sort of sub-regional variation, a natural method of analysis is the inclusion of a state-by-year fixed effect. However, as the sample includes many cities which singularly represent their states, the use of such a method would require the selection of only those cities in the Northeast and Midwest United States. The use of a state-specific time trend is a sort of compromise then, controlling for those similar trends within each state while allowing the inclusion of cities that may be the only area represented within its state. The model is as described in the above subsection, but with a state-specific trend variable substituted for the city specific trend variable $g_{i} * t$. Results from this model are given in Table B2.

After inclusion of the state-specific trend variable, the coefficient on conservation of child life is slightly attenuated (although not as much as when the city-specific trends were included), but it remains economically and statistically significant. The coefficients on charity for children and mothers and outdoor care of poor remain insignificant both economically and statistically.

\section{B.3 Distributed lags}

The third robustness check includes the full lag structure for each of the independent variables included in the model outlined in Section 6. Here, equation (1) is estimated including both the first and second lags for each of these variables. Specifically, the following model is estimated: 
Fox \& Myrskylä: Urban fertility responses to local government programs

$$
\begin{aligned}
& G_{F R_{i, t}}=\beta_{1} C C L_{i, t-1}+\beta_{2} C C L_{i, t-2}+\beta_{3} C C M_{i,-1}+\beta_{4} C C M_{i,-2} \\
& +\beta_{5} O C P_{i, t-1}+\beta_{6} O C P_{i, t-2}+\beta_{7} I M R_{i, t-1}+\beta_{8} I M R_{i-t-2} \\
& +\sum_{j=1}^{J} \delta_{j} X_{j, i, t-1}+\sum_{j=1}^{J} \alpha_{j} X_{j, i, t-2}+\gamma_{1} C_{i}+\gamma_{2} Y_{t}+\epsilon_{i, t}
\end{aligned}
$$

Estimates for the key spending variables $C C L_{i}, C C M_{i}$, and $O C P_{i}$ are given in Table B3. Inclusion of the first and second lags for each of the independent variables did very slightly attenuate the coefficient on conservation of child life by about 0.03 units, although the precision of the coefficient estimate slightly increased. Inclusion of the first and second lags also led to a slight increase of the coefficient point estimate on the first lag of charity for children and mothers. This increase was enough to result in a coefficient estimate statistically significant at the 10 percent level, suggesting, as did the model controlling for city-specific trends, that spending on charity for children and mothers was positively associated with fertility increases. Given that it is not a consistent result across all of the other models estimated, we do not wish to speculate too much regarding its importance. However, it does seem fertility increases followed investments in mothers' pensions and charity for children.

\section{B.4 Arellano-Bond Dynamic Panel Model}

So far the effect of prior period fertility has been controlled for using year fixed effects or the random trend variable $g_{i} * t$. Another method of controlling for prior trends is the inclusion of an autoregressive term $y_{i, t-1}$. Because use of the lagged dependent variable introduces endogeneity, unbiased coefficient estimates require an IV approach such as that introduced by Arellano and Bond (1991). Model (1) from Section 6 with the instrumented lagged dependent variable is given here: 


$$
\begin{gathered}
G F R_{i, t}=\widehat{\widehat{G F R}}_{i, t-1}+\beta_{1} C C L_{i . t-2}+\beta_{2} C C M_{i, t-1}+\beta_{3} O C P_{i, t-1} \\
+\beta_{4} I M R_{i, t-1}+\sum_{j=1}^{J} \delta_{j} X_{j, i, t-1}+\gamma_{1} C_{i}+\lambda_{2} Y_{t}+\epsilon_{i, t}
\end{gathered}
$$

where

$$
\begin{gathered}
\widehat{\widehat{G F R}}_{i, t-1}=\beta_{1} C C L_{i, t-3}+\beta_{2} C C M_{i, t-2}+\beta_{3} O C P_{i, t-2} \\
+\beta_{4} I M R_{i, t-2}+\sum_{j=1}^{J} \delta_{j} X_{j, i-t-2}+\lambda_{1} C_{i}+\lambda_{2} Y_{t-1}+\epsilon_{i, t-1}
\end{gathered}
$$

results from the Arellano-Bond model are given in Table B4. Inclusion of the instrumented lagged dependent variable caused many of the coefficients to differ from the estimates produced in Table 6. However, the coefficient on conservation of child life was only attenuated by about 12 percent and remains negative and statistically and economically significant.

The coefficient on the instrumented lagged dependent variable was both positive and statistically significant, indicating that a city with negative change in fertility one year was likely to see a negative change in fertility the next. As in the models controlling for city-specific trends and the first and second lags of the independent variables, the coefficient on lagged charity for children and mothers spending was positive and statistically significant. 
Fox \& Myrskylä: Urban fertility responses to local government programs

Table B1: City-specific trend results

\begin{tabular}{|c|c|c|}
\hline Dependent variable: Scaled GFR & (1) & (2) \\
\hline \multicolumn{3}{|l|}{ Municipal health and welfare spending } \\
\hline \multirow[t]{2}{*}{ Conservation of child life (2 yr lag) } & $-2.054^{*}$ & $-1.575+$ \\
\hline & $(0.988)$ & $(0.799)$ \\
\hline \multirow[t]{2}{*}{ Charity for children and mothers } & 0.636 & $0.934+$ \\
\hline & $(0.509)$ & $(0.483)$ \\
\hline \multirow[t]{2}{*}{ Outdoor care of poor } & $-0.243^{*}$ & -0.0291 \\
\hline & $(0.109)$ & $(0.090)$ \\
\hline \multirow[t]{2}{*}{ Infant mortality rate } & & $0.0019^{*}$ \\
\hline & & $(0.001)$ \\
\hline \multicolumn{3}{|l|}{ Other spending variables ${ }^{1}$} \\
\hline \multirow[t]{2}{*}{ Other health spending } & & $-0.596^{*}$ \\
\hline & & $(0.282)$ \\
\hline \multirow[t]{2}{*}{ Sanitation spending } & & 0.098 \\
\hline & & $(0.155)$ \\
\hline \multirow[t]{2}{*}{ Hospital spending } & & -0.287 \\
\hline & & $(0.186)$ \\
\hline \multirow[t]{2}{*}{ Spending on schools and libraries } & & -0.0385 \\
\hline & & $(0.065)$ \\
\hline \multicolumn{3}{|l|}{ Personal income/Economic outcome vars } \\
\hline \multirow[t]{2}{*}{ Manufacturing wages per worker } & & $0.0049^{* *}$ \\
\hline & & $(0.001)$ \\
\hline \multirow[t]{2}{*}{ Proportion of adults in manufacturing } & & $1.452^{*}$ \\
\hline & & $(0.681)$ \\
\hline \multirow[t]{2}{*}{ Population proportion filing taxes } & & 0.8631 \\
\hline & & $(0.817)$ \\
\hline \multirow[t]{2}{*}{ Constant } & $2.899^{* *}$ & $1.429^{\star *}$ \\
\hline & $(0.052)$ & $(0.329)$ \\
\hline City specific trend & Y & $\mathrm{Y}$ \\
\hline State specific trend & $\mathrm{N}$ & $\mathrm{N}$ \\
\hline City fixed effects & $\mathrm{Y}$ & $\mathrm{Y}$ \\
\hline Year fixed effects & $\mathrm{Y}$ & $\mathrm{Y}$ \\
\hline Observations & 494 & 486 \\
\hline Within $\mathrm{R}$ squared & 0.890 & 0.913 \\
\hline
\end{tabular}

Notes: Robust standard errors in parentheses. ${ }^{* \star} p<0.01,{ }^{*} p<0.05,+p<0.1$.

Scaled GFR is a city General Fertility Rate, scaled as described in Section 3. Government expenditures are per 100 persons and adjusted to 2011 dollars. Unless otherwise noted, all variables are set at one year lags. 


\section{Table B2: New dependent variables results}

\begin{tabular}{|c|c|c|}
\hline Dependent variable: Scaled GFR & (1) & (2) \\
\hline \multicolumn{3}{|l|}{ Municipal health and welfare spending } \\
\hline Conservation of child life (2 yr lag) & $\begin{array}{l}-1.649 \\
(1.613)\end{array}$ & $\begin{array}{l}-1.845+ \\
(0.983)\end{array}$ \\
\hline Charity for children and mothers & $\begin{array}{l}-0.214 \\
(0.330)\end{array}$ & $\begin{array}{c}0.433 \\
(0.314)\end{array}$ \\
\hline Outdoor care of poor & $\begin{array}{l}-0.085 \\
(0.097)\end{array}$ & $\begin{array}{l}0.007 \\
(0.061)\end{array}$ \\
\hline Infant mortality rate & & $\begin{array}{r}0.002^{*} \\
(0.001)\end{array}$ \\
\hline \multicolumn{3}{|l|}{ Other spending variables } \\
\hline Other health & & $\begin{array}{l}-0.768^{* *} \\
(0.233)\end{array}$ \\
\hline Sanitation & & $\begin{array}{c}0.033 \\
(0.166)\end{array}$ \\
\hline Hospitals & & $\begin{array}{l}-0.097 \\
(0.203)\end{array}$ \\
\hline Schools and libraries & & $\begin{array}{c}0.056 \\
(0.066)\end{array}$ \\
\hline \multicolumn{3}{|l|}{ Personal income/Economic } \\
\hline $\begin{array}{l}\text { Manufacturing wages per } \\
100 \text { workers }\end{array}$ & & $\begin{array}{c}0.0038^{*} \\
(0.002)\end{array}$ \\
\hline Proportion adults in manufacturing & & $\begin{array}{l}2.097^{* *} \\
(0.561)\end{array}$ \\
\hline Population proportion filing taxes & & $\begin{array}{c}1.368 \\
(0.990)\end{array}$ \\
\hline \multicolumn{3}{|l|}{ Municipal } \\
\hline Proportion in city female \& aged $15-44$ & & $\begin{array}{l}-0.178 \\
(4.417)\end{array}$ \\
\hline Proportion black female \& aged $15-44$ & & $\begin{array}{l}-1.705 \\
(2.925)\end{array}$ \\
\hline Proportion foreign born female $\&$ age $15-44$ & & $\begin{array}{c}0.968 \\
(1.492)\end{array}$ \\
\hline Proportion over 10 and illiterate & & $\begin{array}{c}8.579 \\
(7.142)\end{array}$ \\
\hline \multicolumn{3}{|l|}{ Other } \\
\hline Proportion of women over age 15 married & & $\begin{array}{r}6.648^{*} \\
(2.819)\end{array}$ \\
\hline Proportion church membership Roman Catholic & & $\begin{array}{l}-3.133^{\star *} \\
(1.127)\end{array}$ \\
\hline County population density & & $\begin{array}{l}-0.000049^{*} \\
(0.00002)\end{array}$ \\
\hline Constant & $\begin{array}{l}2.916^{\star *} \\
(0.060)\end{array}$ & $\begin{array}{l}-1.352 \\
(2.058)\end{array}$ \\
\hline City fixed effects & Y & $\mathrm{Y}$ \\
\hline Year fixed effects & Y & Y \\
\hline State specific trends & Y & Y \\
\hline Observations & 486 & 486 \\
\hline Within R-squared & 0.800 & 0.870 \\
\hline
\end{tabular}

Notes: Scaled GFR is a city General Fertility Rate, scaled as described in Section 3.

Robust standard errors in parentheses. ${ }^{* *} p<0.01,{ }^{*} p<0.05,+p<0.1$. Government expenditures are per 100 persons and adjusted to 2011 dollars. Unless otherwise noted, all variables are set at one year lags. 
Fox \& Myrskylä: Urban fertility responses to local government programs

\section{Table B3: Distributed lag model results}

\begin{tabular}{lc}
\hline Dependent var: & Scaled GFR \\
\hline $\begin{array}{c}\text { Municipal health and welfare spending } \\
\text { Conservation of child life } \\
\text { 1st lag }\end{array}$ & 0.767 \\
& $(0.895)$ \\
2nd lag & $-1.908^{*}$ \\
& $(0.722)$ \\
Charity for children and mothers & \\
1st lag & $0.530+$ \\
& $(0.294)$ \\
2nd lag & 0.207 \\
Outdoor care of poor & $(0.333)$ \\
1st lag & \\
2nd lag & 0.017 \\
& $(0.082)$ \\
Constant & 0.151 \\
Year fixed effects & $(0.264)$ \\
Adjusted R-squared & \\
\hline
\end{tabular}

Notes: Both the first and second lags for all of the other covariates (listed in Section 6) are also included in the estimation model. Robust standard errors in parentheses. ${ }^{* *} p<0.01,{ }^{*} p<0.05,+p<0.1$. Government expenditures are per 100 persons and adjusted to 2011 dollars. 
Table B4: Arellano-Bond model results

\begin{tabular}{|c|c|}
\hline Dependent variable: & Scaled GFR \\
\hline \multirow[t]{2}{*}{ Lagged dependent variable } & $0.370^{* *}$ \\
\hline & $(0.133)$ \\
\hline \multicolumn{2}{|l|}{ Municipal health and welfare spending } \\
\hline \multirow[t]{2}{*}{ Conservation of child life ( 2 yr lag) } & $-1.704^{\star *}$ \\
\hline & $(0.571)$ \\
\hline \multirow[t]{2}{*}{ Charity for children and mothers } & $0.671^{*}$ \\
\hline & $(0.294)$ \\
\hline \multirow[t]{2}{*}{ Outdoor care of poor } & -0.018 \\
\hline & $(0.069)$ \\
\hline \multirow[t]{2}{*}{ Infant mortality rate } & 0.001 \\
\hline & $(0.001)$ \\
\hline \multicolumn{2}{|l|}{ Other spending variables } \\
\hline \multirow[t]{2}{*}{ Other health spending } & $-0.772^{* *}$ \\
\hline & $(0.223)$ \\
\hline \multirow[t]{2}{*}{ Sanitation spending } & -0.027 \\
\hline & $(0.127)$ \\
\hline \multirow[t]{2}{*}{ Hospital spending } & -0.080 \\
\hline & $(0.198)$ \\
\hline \multirow[t]{2}{*}{ Spending on schools and libraries } & -0.002 \\
\hline & $(0.053)$ \\
\hline \multicolumn{2}{|l|}{ Personal income/Economic outcome vars } \\
\hline \multirow[t]{2}{*}{ Manufacturing wages per worker } & $0.0033^{* *}$ \\
\hline & $(0.001)$ \\
\hline \multirow[t]{2}{*}{ Proportion of adults in manufacturing } & $0.944^{\star}$ \\
\hline & $(0.395)$ \\
\hline \multirow[t]{2}{*}{ Population proportion filing taxes } & 0.936 \\
\hline & $(0.639)$ \\
\hline \multicolumn{2}{|l|}{ Municipal } \\
\hline & 3.666 \\
\hline \multirow[t]{2}{*}{ Proportion in city female \& aged $15-44$} & (3.408) \\
\hline & -0.215 \\
\hline \multirow[t]{2}{*}{ Proportion black female \& aged $15-44$} & $(1.299)$ \\
\hline & 1.083 \\
\hline Proportion foreign born female \& age $15-44$ & $(1.257)$ \\
\hline \multirow[t]{2}{*}{ Proportion over 10 and illiterate } & -1.726 \\
\hline & $(4.483)$ \\
\hline \multicolumn{2}{|l|}{ Other } \\
\hline \multirow[t]{2}{*}{ Proportion of women over age 15 married } & 2.125 \\
\hline & $(1.982)$ \\
\hline \multirow[t]{2}{*}{ Proportion church membership Roman Catholic } & -0.948 \\
\hline & $(1.058)$ \\
\hline \multirow[t]{2}{*}{ County population density } & 0.0000038 \\
\hline & $(0.00002)$ \\
\hline Constant & -1.099 \\
\hline & $(1.611)$ \\
\hline City fixed effects & Y \\
\hline Year fixed effects & Y \\
\hline Observations & 422 \\
\hline Number of panelid & 64 \\
\hline
\end{tabular}

Notes: Scaled GFR is a city General Fertility Rate, scaled as described in Section 3.

Robust standard errors in parentheses. ${ }^{* *} p<0.01,{ }^{*} p<0.05,+p<0.1$. Government expenditures are per 100 persons and adjusted to 2011 dollars. Unless otherwise noted, all variables are set at one year lags. 


\section{Data appendix}

The dataset contains annual information on a set of 64 cities between 1923 and 1932 . These are cities over 100,000 persons in 1920, as that was the cutoff used in publications for much of the necessary financial and Census data, and part of the Birth Registration Area at some point during the sample period. Table $\mathrm{C} 1$ lists those cities which are part of the analysis, along with the other states which did not contain a sample city. Each city is listed with its entry date into the BRA.

The start date of 1923 was chosen for data availability reasons. Although the financial statistics for cities were first published by the Department of Commerce in 1906, they were not published in 1920 because all available Census workers being focused on the national census. Additionally, in an effort to save costs in 1921 and 1922, the Bureau tried sending out questionnaires to the different cities. Some of the necessary financial details are missing for those years, and those which exists are of questionable quality. The year 1923 was the first in which there is reliable financial information and the public programs of interest show up in government outlays.

Manufacturing earnings were entered from the Biannual Census of Manufactures volumes to help control for municipal income. As the Census of Manufactures was published every other year, the even numbered years represent linear interpolations.

In order to calculate population densities (population per square mile), the land area of the different counties was determined from the Decennial Censuses. When information on the land area of a county was missing, it was determined by the next closest date in the future for which the information was available. For instance, if the land area was missing for 1920 , the 1930 value was used. If it was also missing for 1930 , then the 1940 value was used, and so on. In most cases the counties did not expand, however there were some exceptions, such as Orleans Parish in Louisiana and Fulton County in Georgia.

The financial statistics and manufacturing wages are inflated to 2011 dollars. This was done using the CPI calculations from Williamson (2015) available on the MeasuringWorth website. Although there was very little change in the price index during the first part the 1920s, there was some level of depreciation towards the end and into the early 1930s. 
Table C1: List of sample cities

\begin{tabular}{|c|c|c|c|c|c|}
\hline City Name & State & Year entered BRA & City Name & State & Year entered BRA \\
\hline Birmingham & $\mathrm{AL}$ & 1927 & Akron & $\mathrm{OH}$ & 1917 \\
\hline Los Angeles & $\mathrm{CA}$ & 1919 & Cincinnati & $\mathrm{OH}$ & 1917 \\
\hline Oakland & $\mathrm{CA}$ & 1919 & Cleveland & $\mathrm{OH}$ & 1917 \\
\hline San Francisco & $\mathrm{CA}$ & 1919 & Columbus & $\mathrm{OH}$ & 1917 \\
\hline Denver & $\mathrm{CO}$ & 1928 & Dayton & $\mathrm{OH}$ & 1917 \\
\hline Bridgeport & $\mathrm{CT}$ & 1915 & Toledo & $\mathrm{OH}$ & 1917 \\
\hline Hartford & $\mathrm{CT}$ & 1915 & Youngstown & $\mathrm{OH}$ & 1917 \\
\hline New Haven & CT & 1915 & Portland & OR & 1919 \\
\hline Washington D.C. & DC & 1915 & Philadelphia & PA & 1915 \\
\hline Wilmington & DE & 1921 & Pittsburgh & PA & 1915 \\
\hline Atlanta & GA & 1928 & Reading & PA & 1915 \\
\hline Chicago & $\mathrm{IL}$ & 1922 & Scranton & PA & 1915 \\
\hline Indianapolis & IN & 1917 & Providence & $\mathrm{RI}$ & 1915 \\
\hline Des Moines & 10 & 1924 & Memphis & TN & 1927 \\
\hline Kansas City & KS & 1917 & Nashville & $\mathrm{TN}$ & 1927 \\
\hline Louisville & KY & 1917 & Salt Lake City & UT & 1917 \\
\hline New Orleans & LA & 1927 & Norfolk & VA & 1917 \\
\hline Boston & MA & 1915 & Richmond & VA & 1917 \\
\hline Cambridge & MA & 1915 & Seattle & WA & 1917 \\
\hline Fall River & MA & 1915 & Spokane & WA & 1917 \\
\hline Lowell & MA & 1915 & Milwaukee & WI & 1917 \\
\hline New Bedford & MA & 1915 & & & \\
\hline Springfield & MA & 1915 & Other States Not Listed & & \\
\hline Worcester & MA & 1915 & Arizona & $A Z$ & 1926 \\
\hline Baltimore & MD & 1916 & Arkansas & AR & 1926 \\
\hline Detroit & MI & 1915 & Florida & $\mathrm{FL}$ & 1924 \\
\hline Grand Rapids & MI & 1915 & Idaho & ID & 1926 \\
\hline Minneapolis & $\mathrm{MN}$ & 1915 & Maine & ME & 1915 \\
\hline St. Paul & $\mathrm{MN}$ & 1915 & Mississippi & MS & 1921 \\
\hline Kansas City & MO & 1927 & Montana & MT & 1922 \\
\hline St. Louis & MO & 1927 & Nevada & NV & 1929 \\
\hline Omaha & $\mathrm{NE}$ & 1920 & New Hampshire & $\mathrm{NH}$ & 1915 \\
\hline Camden & $\mathrm{NJ}$ & 1921 & New Mexico & NM & 1929 \\
\hline Jersey City & $\mathrm{NJ}$ & 1921 & North Carolina & NC & 1917 \\
\hline Newark & $\mathrm{NJ}$ & 1921 & North Dakota & ND & 1924 \\
\hline Paterson & $\mathrm{NJ}$ & 1921 & Oklahoma & OK & 1928 \\
\hline Trenton & NJ & 1921 & South Carolina & SC & 1928 \\
\hline Albany & NY & 1915 & South Dakota & SD & 1932 \\
\hline Buffalo & NY & 1915 & Texas & TX & 1933 \\
\hline New York & NY & 1915 & Vermont & VT & 1915 \\
\hline Rochester & NY & 1915 & West Virginia & WV & 1925 \\
\hline Syracuse & NY & 1915 & Wyoming & WY & 1922 \\
\hline Yonkers & NY & 1915 & & & \\
\hline
\end{tabular}

Source: Birth, Stillbirth, and Infant Mortality Statistics for the Continental United States, the Territory of Hawaii, The Virgin Islands: 1933 
Fox \& Myrskylä: Urban fertility responses to local government programs 